\title{
LAS CLÁUSULAS ABUSIVAS EN LOS CONTRATOS DE CRÉdITO HIPOTECARIO. UNA MIRADA COMPARATIVA ENTRE ESPAÑA Y COLOMBIA*
}

\section{ABUSIVE CLAUSES IN THE MORTGAGE LOAN CREDITS. A COMPARATIVE LOOK BETWEEN SPAIN AND COLOMBIA}

\author{
Mariana Bernal-Fandiño** \\ Fernando Andrés Pico-Zúñiga**** \\ Fecha de recepción: 23 de julio de 2015 \\ Fecha de aceptación: 02 de septiembre de 2015 \\ Disponible en linea: 30 de noviembre de 2015
}

\section{Para citar este artículo/To cite this article}

\begin{abstract}
Bernal-Fandiño, Mariana \& Pico-Zúñiga, Fernando Andrés, Las cláusulas abusivas en los contratos de crédito hipotecario. Una mirada comparativa entre España y Colombia, 131 Vniversitas, 149-194 (2015). http://dx.doi. org/10.11144/Javeriana.vj131.cacc

doi:10.11144/Javeriana.vj131.cacc
\end{abstract}

* Este texto es un producto del programa de investigación Debates contemporáneos del derecho privado, adelantado por el grupo de investigación en Derecho Privado, Universidad Sergio Arboleda.

** Abogada, Pontificia Universidad Javeriana. Máster 2 en derecho comercial y máster 2 en derecho internacional privado, Universidad de París II. Doctora en ciencias jurídicas, Pontificia Universidad Javeriana. Actualmente, es profesora investigadora de la Escuela de Derecho, Universidad Sergio Arboleda. Contacto: mariana.bernal@usa.edu.co

*** Abogado, Pontificia Universidad Javeriana. Magíster en derecho de la empresa y de los negocios, Universidad de Barcelona. Miembro del grupo de investigación en Derecho Privado, Facultad de Ciencias Jurídicas, Pontificia Universidad Javeriana. En la actualidad se desempeña como asesor jurídico de la presidencia de la Federación Nacional de Comerciantes (FENALCO). Contacto: fpz14@hotmail.com 


\section{RESUMEN}

Este artículo pretende realizar un estudio sobre las cláusulas abusivas en los contratos de crédito hipotecario bajo una mirada comparativa entre la evolución que ha tenido la materia durante la reciente crisis inmobiliaria en España y la situación jurídica en Colombia, que atravesó una crisis similar a finales de los años noventa y hoy cuenta con el amparo primordial del Estatuto del Consumidor, el régimen de protección del consumidor financiero, entre otros. Se analizan mecanismos interpretativos del activismo judicial y hasta cierto punto externos al Derecho Privado - supranacionales y constitucionales - que han generado a su vez cambios legislativos en ambos países.

Palabras clave: protección al consumidor; crisis inmobiliaria; cláusulas abusivas 


\section{ABSTRACT}

This article aims to conduct a study on on abusive clauses in the mortgage loans contracts. Following a comparative look between the evolution of the subject matter during the recent real estate crisis in Spain and the legal situation in Colombia, which underwent a similar crisis during the late nineties and today has the fundamental protection of the Consumer Code, the protection regime of the financial consumer, among others. We analyze interpretive mechanisms of legal activism and, up to certain extent, external to Private Law - supranational and constitutional -, which, at the same time, generated legal changes in both countries.

Keywords: consumer protection; real estate crisis; abusive clauses

\section{SUMARIO}

INTRODUCCIÓN.- I. LA CRISIS HIPOTECARIA. El CONTEXTO ESPAÑOL Y EL COLOMBIANo.- A. Breves apuntes acerca del escenario jurídico alrededor de la crisis hipotecaria española.- 1. La cláusula abusiva en el marco del proceso ejecutivo. El caso Aziz, sentencia del 14 de marzo de 2013 del Tribunal de Justicia de la Unión Europea. 2. Las cláusulas "suelo": ¿abusivas o ambiguas? La sentencia del 9 de mayo de 2013 de la Sala Civil del Tribunal Supremo Español.- 3. Algunas consideraciones sobre las providencias españolas.- B. El contexto de Colombia frente a una crisis hipotecaria.- 1. Causas de la crisis.- 2 . Reacción frente a la crisis.- II. LA SITUACIÓN DE LAS Cláusulas abusivas en el derecho contractual colombiano.- $A$. Protección general en el ordenamiento jurídico colombiano frente a las cláusulas abusivas.- 1. Protección constitucional.- 2. Protección legal.- 3. Protección especial.- a. Protección al consumidor financiero.- 4. Aplicación de la norma especial.- ConCLUSIONES.- BiBliografía. 


\section{INTRODUCCIÓN}

En las crisis se ha transformado el Derecho o, por lo menos, ha entrado en cuestionamiento. La crisis subprime, originada hacia 2007 en Estados Unidos, con fuertes implicaciones negativas de orden internacional en el ámbito económico, sociológico, político, etc., también ha afectado a la ciencia jurídica y, en consecuencia, ha llevado a su controversia, por qué no, innovación, particularmente en campos como el del crédito hipotecario.

Así, vale recordar que los créditos subprime eran un tipo especial de crédito hipotecario caracterizado por un elevado nivel de riesgo, en virtud de su baja calificación crediticia o de la escasa solvencia de un segmento de la población para su pago. Dado el desconocimiento del riesgo real, al parecer por una mala calificación de los títulos o bonos representativos de los créditos, los bancos y entidades de inversión en el mercado global se hicieron a los instrumentos financieros lo que ocasionó el fenómeno de credit crush, esto es, una contracción del crédito que representó un repentino incremento del costo de obtener préstamos bancarios o la reducción del dinero disponible para prestar. Este hecho generó, a su vez, la extensión de la desconfianza de los inversores y consumidores, con la consecuente baja de los valores bursátiles y una falta de liquidez generalizada en los mercados.

Como resultado, la Reserva Federal de Estados Unidos hizo un alza progresiva de la tasa de interés, lo que se tradujo en un aumento de las cuotas hipotecarias, lo cual además de marcar el comienzo de la crisis, supuso el incremento de la tasa de morosidad y del nivel de ejecuciones. La situación generó un pánico financiero que se trasladó a la economía global en 2008, con énfasis en Europa.

En efecto, en el viejo continente también se presentó el mismo fenómeno de la contracción del crédito; no solo ello, se evidenció un aumento paulatino del Euríbor - Euro Interbank Offered Rate o índice de referencia de la tasa de interés para Europa-, lo cual generó el mismo efecto negativo observado en Estados Unidos: la desconfianza en los consumidores europeos. Para el caso español, además de estas variables negativas, desde mediados de la década del ochenta, se experimentó un incremento exorbitante en los precios de los inmuebles que se agudizó mucho más entre 2001 y 2008, 
fecha en la que se produjeron el estallido de la burbuja inmobiliaria y la crisis subprime. Por otra parte, a esto se aunó la existencia de una elevada tasa de desempleo que terminó por colapsar la situación económica.

Estos hechos llevaron en España a un número elevado de desahucios. Las personas desempleadas y sin la posibilidad de acordar créditos más favorables, no podían pagar sus deudas hipotecarias que se iban incrementando rápidamente.

El contexto jurídico español favoreció esta circunstancia. En efecto, siguiendo a Ana Isabel Blanco García, las entidades de crédito - acreedoras - reaccionaron ante los incumplimientos con la acción de ejecución hipotecaria, instrumento procesal mediante el cual se ordena la venta del bien inmueble gravado con una hipoteca para hacer efectivo su importe y pagar las deudas contraídas ${ }^{1}$.

El citado procedimiento en España está regulado entre los artículos 681 a 698 de la Ley 1/2000, Ley de Enjuiciamiento Civil (en adelante, LEC $^{2}$ ). Así, en un principio, aunque la vivienda fuera objeto de ejecución, si el dinero obtenido de su venta forzosa no era suficiente para saldar la deuda, es decir, no cubría toda la cuantía debida al banco, el deudor seguía respondiendo por la diferencia, con el resto de sus bienes presentes y futuros. En otras palabras, no se admitía la dación en pago como forma de extinción de la obligación crediticia. Además de presentarse cláusulas abusivas en el contrato de crédito hipotecario, el consumidor no podía exigir su nulidad en el proceso ejecutivo, a la luz de las normas vigentes en ese momento.

Ante el escenario crítico de desahucios y la alta tasa de desempleo vivida en España, la doctrina y los juzgadores se preguntaron si el juez, conforme a las normas reguladoras de las cláusulas abusivas del consumidor - Texto Refundido de la Ley General para la Defensa de los Consumidores y Usuarios, Real Decreto Legislativo 1/2007 (en adelante, TRLCU ${ }^{3}$ ) - y las reglas de la LEC en materia

1 Ana Isabel Blanco-García, Control de oficio de las cláusulas abusivas en la ejecución hipotecaria, 7 Revista CESCO de Derecho de Consumo, 195-217 (2013). Disponible en: https://cesco. revista.uclm.es/index.php/cesco/article/view/337/312

2 España, Ley 1/2000, de 7 de enero, Ley de Enjuiciamiento Civil, 7 Boletín Oficial del Estado, $B O E, 8$ de enero de 2000. Disponible en: http://www.boe.es/boe/dias/2000/01/08/pdfs/A0057500728.pdf

3 España, Real Decreto Legislativo 1/2007, de 16 de noviembre, por el que se aprueba el texto refundido de la Ley General para la Defensa de los Consumidores y Usuarios y otras leyes 
de ejecución hipotecaria, podría declarar de manera oficiosa la nulidad de las cláusulas abusivas que encontrara en el negocio.

La discusión y su resolución mediante pronunciamientos jurisprudenciales en el ámbito tanto europeo como español, llevaron a un ejercicio mucho más proactivo de los juzgadores frente al examen de los contratos de crédito hipotecario, en particular en lo que tiene qué ver con el hecho de declarar la nulidad de sus cláusulas abusivas, y la expedición de nuevas leyes modificatorias del régimen procesal en materia de ejecución hipotecaria dirigidas a beneficiar al consumidor y, en concreto, a permitir que el deudor pudiera solicitar la declaratoria de abusivas de las cláusulas en el marco de los procesos ejecutivos ${ }^{4}$.

Ahora, en el contexto jurídico y económico colombiano no se han sentido con enorme impacto las consecuencias de la crisis subprime. Sin embargo, desde hace algunos años se ha venido identificando un incremento masivo en los precios de los inmuebles que, si bien no es confrontable con la situación prevista en España, a partir del derecho comparado, sí llaman la atención las consecuencias que este hecho podría llegar a tener en el ámbito de los créditos hipotecarios y su relación con las cláusulas abusivas. Aunado a ello, no debe olvidarse la fuerte crisis financiera que azotó al país entre los años 1998 y 2001, la cual llevó a la expedición de los Decretos 2330 y 2331 de 1998, así como a la Ley 546 de $1999^{5}$ —reglamentaria del sector

complementarias, 287 Boletín Oficial del Estado, BOE, 30 de noviembre de 2007. Disponible en: http://www.boe.es/buscar/act.php?id=BOE-A-2007-20555

4 Al respecto, José María Fernández-Seijo explica: "probablemente el efecto más evidente del llamado caso Aziz ha sido la modificación de la Ley de Enjuiciamiento Civil, llevada a efecto por la Ley 1/2013, de mayo de 2013. En su exposición de motivos se hace referencia expresa a la Sentencia del TJUE de marzo de 2013. La Ley 1/2013 no solo pretende adaptar la legislación procesal española a la sentencia — probablemente (sic) no hacía falta-, sino que aprovecha la ocasión para introducir novedades sustanciales en cuanto a los procesos de ejecución, sobre todo contra viviendas". José María Fernández-SeiJo, Un año después de la Sentencia del caso Aziz, 286 Revista Món Jurídic, Revista del Ilustre Colegio de Abogados de Barcelona, 16-17 (2014). Disponible en: http://dialnet.unirioja.es/servlet/articulo?codigo=4680285

5 Decreto 2330 de 1998, por el cual se declara el Estado de Emergencia Económica y Social, 43.430 Diario Oficial, 16 de noviembre de 1998. Disponible en: http://www.secretariasenado.gov.co/ senado/basedoc/decreto_2330_1998.html. Decreto 2331 de 1998, por el cual se dictan medidas tendientes a resolver la situación de los sectores financiero y cooperativo, aliviar la situación de los deudores por créditos de vivienda y de los ahorradores de las entidades cooperativas en liquidación, mediante la creación de mecanismos institucionales y de financiación y la adopción de disposiciones complementaria, 43.430 Diario Oficial, 16 de noviembre de 1998. Disponible en: http://www.secretariasenado.gov.co/senado/basedoc/decreto_2331_1998.htm. Ley 546 de 1999, por la cual se dictan normas en materia de vivienda, se señalan los objetivos y criterios generales a los cuales debe sujetarse el Gobierno Nacional para regular un siste- 
hipotecario, también conocida como Ley UVR - e importantes pronunciamientos jurisprudenciales de orden constitucional, que solventaron la crítica situación.

Por ese motivo, aunque en el escenario jurídico colombiano contamos en la actualidad con una aún novedosa legislación de protección al consumidor - Ley 1480 de 2011, Estatuto del Consumidor y Ley 1328 de 2009, Régimen de protección al consumidor financiero ${ }^{6}$ - , la cual regula, para lo que interesa, la materia de las cláusulas abusivas, se hace imperioso analizar la materia en línea con el contexto jurídico y la realidad socioeconómica extranjera y nacional.

De esta manera, el presente trabajo tiene como objetivo central estudiar las cláusulas abusivas en el campo de los contratos de crédito hipotecario bajo una mirada comparativa entre la evolución que ha tenido la materia durante la reciente crisis inmobiliaria en España y la situación jurídica del asunto en Colombia, al amparo primordialmente del Estatuto del Consumidor, el régimen de protección del consumidor financiero y fuentes complementarias. Todo ello, a sabiendas de que han sido los mecanismos interpretativos de proactivismo judicial y hasta cierto punto externos al Derecho Privado - supranacionales y constitucionales - los que han permitido encontrarle una solución a la situación.

Así, guiados por ese propósito, el documento se divide en dos grandes acápites. Primero, el relativo al análisis de la crisis hipotecaria en España y sus homólogas en Colombia, en el que se abordarán, desde una perspectiva mucho más jurídica que económica, las implicaciones de las cláusulas abusivas en los contratos de crédito hipotecario en cada uno de los países. Segundo, a partir de un mirada propositiva y de revisión, se efectuará el estudio de las cláusulas abusivas en el Derecho colombiano, con énfasis en los

ma especializado para su financiación, se crean instrumentos de ahorro destinado a dicha financiación, se dictan medidas relacionadas con los impuestos y otros costos vinculados a la construcción y negociación de vivienda y se expiden otras disposiciones, 43.827 Diario Oficial, 23 de diciembre de 1999. Disponible en: http://www.secretariasenado.gov.co/senado/ basedoc/ley_0546_1999.htm

6 Ley 1480 de 2011, por medio de la cual se expide el Estatuto del Consumidor y se dictan otras disposiciones, 48.220 Diario Oficial, 12 de octubre de 2011. Disponible en: http://www. secretariasenado.gov.co/senado/basedoc/ley_1480_2011.html. Ley 1328 de 2009, por la cual se dictan normas en materia financiera, de seguros, del mercado de valores y otras disposiciones, 47.411 Diario Oficial, 15 de julio de 2009. Disponible en: http://www.secretariasenado.gov.co/ senado/basedoc/ley_1328_2009.html 
contratos de crédito hipotecario y las alternativas de protección que tiene el consumidor en ese ámbito. Por último, se ofrecerán algunas conclusiones.

\section{LA CRISIS HIPOTECARIA. EL CONTEXTO ESPAÑOL Y EL COLOMBIANO}

\section{A. Breves apuntes acerca del escenario jurídico alrededor de la crisis hipotecaria española}

Como se ha indicado, la crisis hipotecaria española de 2008, representada principalmente en los innumerables desahucios por vía ejecutiva, generó fuertes debates en torno a la regulación de las cláusulas abusivas en los contratos de crédito hipotecario y su aplicación en el campo procesal.

En efecto, la grave realidad socioeconómica acaecida en España llevó a que los juzgadores, principales receptores de los procesos ejecutivos, reconocieran la problemática y se encaminaran hacia una solución que permitiera una efectiva protección de los intereses del consumidor hipotecario a la luz de las normas nacionales y comunitarias.

El escenario jurídico español presentó hasta 2013, desde el ámbito procesal y sustancial, en lo que tiene qué ver con los procesos ejecutivos y las cláusulas abusivas, varios inconvenientes a los que tuvieron que enfrentarse los jueces: i. Los contratos hipotecarios no eran objeto de análisis de fondo, simplemente materia de ejecución. ii. El consumidor no podía solicitar la nulidad de una cláusula abusiva — en los términos del TRLCU — porque el artículo 695 de la LEC, propio del juicio ejecutivo hipotecario, establecía taxativamente las excepciones que el demandado podía alegar, entre las que no se encontraba aquella ${ }^{7}$. iii. Como consecuencia de lo anterior,

7 El artículo 695 de la LEC, antes de su modificatoria en 2013, establecía: "Artículo 695. Oposición a la ejecución. 1. En los procedimientos a que se refiere este capítulo solo se admitirá la oposición del ejecutado cuando se funde en las siguientes causas: 1. Extinción de la garantía o de la obligación garantizada, siempre que se presente certificación del Registro expresiva de la cancelación de la hipoteca o, en su caso, de la prenda sin desplazamiento, o escritura pública de carta de pago o de cancelación de la garantía. 2. Error en la determinación de la cantidad exigible, cuando la deuda garantizada sea el saldo que arroje el cierre de una cuenta entre ejecutante y ejecutado. El ejecutado deberá acompañar su ejemplar de la libreta en la que consten los asientos de la cuenta y solo se admitirá la oposición cuando el saldo que arroje 


\section{y ante la existencia de una cláusula abusiva en el contrato de hipo- teca, al juzgador no le era dable declarar la nulidad de la cláusula de manera oficiosa. \\ Estas barreras y problemáticas que enfrentaban la regulación de las cláusulas abusivas bajo el artículo 82 y siguientes del TRLCU ${ }^{8}$ y la normativa del proceso ejecutivo de la LEC, derivaron en dos}

dicha libreta sea distinto del que resulte de la presentada por el ejecutante. No será necesario acompañar libreta cuando el procedimiento se refiera al saldo resultante del cierre de cuentas corrientes u operaciones similares derivadas de contratos mercantiles otorgados por entidades de crédito, ahorro o financiación en los que se hubiere convenido que la cantidad exigible en caso de ejecución será la especificada en certificación expedida por la entidad acreedora, pero el ejecutado deberá expresar con la debida precisión los puntos en que discrepe de la liquidación efectuada por la entidad. 3. En caso de ejecución de bienes muebles hipotecados o sobre los que se haya constituido prenda sin desplazamiento, la sujeción de dichos bienes a otra prenda, hipoteca mobiliaria o inmobiliaria o embargo inscritos con anterioridad al gravamen que motive el procedimiento, lo que habrá de acreditarse mediante la correspondiente certificación registral.

2. Formulada la oposición a la que se refiere el apartado anterior, el Secretario judicial suspenderá la ejecución y convocará a las partes a una comparecencia ante el Tribunal que hubiera dictado la orden general de ejecución, debiendo mediar cuatro días desde la citación, comparecencia en la que el Tribunal oirá a las partes, admitirá los documentos que se presenten y acordará en forma de auto lo que estime procedente dentro del segundo día.

3. El auto que estime la oposición basada en las causas 1 y 3 del apartado 1 de este artículo mandará sobreseer la ejecución; el que estime la oposición basada en la causa 2 fijará la cantidad por la que haya de seguirse la ejecución.

4. Contra el auto que ordene el sobreseimiento de la ejecución podrá interponerse recurso de apelación. Fuera de este caso, los autos que decidan la oposición a que se refiere este artículo no serán susceptibles de recurso alguno". España, Ley 1/2000, de 7 de enero, Ley de Enjuiciamiento Civil, 7 Boletín Oficial del Estado, BOE, 8 de enero de 2000. Disponible en: http:// www.boe.es/boe/dias/2000/01/08/pdfs/A00575-00728.pdf

8 "Artículo 82. Concepto de cláusulas abusivas. 1. Se considerarán cláusulas abusivas todas aquellas estipulaciones no negociadas individualmente y todas aquellas prácticas no consentidas expresamente que, en contra de las exigencias de la buena fe causen, en perjuicio del consumidor y usuario, un desequilibrio importante de los derechos y obligaciones de las partes que se deriven del contrato. 2. El hecho de que ciertos elementos de una cláusula o que una cláusula aislada se hayan negociado individualmente no excluirá la aplicación de las normas sobre cláusulas abusivas al resto del contrato. El empresario que afirme que una determinada cláusula ha sido negociada individualmente, asumirá la carga de la prueba. 3. El carácter abusivo de una cláusula se apreciará teniendo en cuenta la naturaleza de los bienes o servicios objeto del contrato y considerando todas las circunstancias concurrentes en el momento de su celebración, así como todas las demás cláusulas del contrato o de otro del que este dependa. 4. No obstante lo previsto en los apartados precedentes, en todo caso son abusivas las cláusulas que, conforme a lo dispuesto en los artículos 85 a 90, ambos inclusive: a) vinculen el contrato a la voluntad del empresario, b) limiten los derechos del consumidor y usuario, c) determinen la falta de reciprocidad en el contrato, d) impongan al consumidor y usuario garantías desproporcionadas o le impongan indebidamente la carga de la prueba, e) resulten desproporcionadas en relación con el perfeccionamiento y ejecución del contrato, o f) contravengan las reglas sobre competencia y derecho aplicable". España, Real Decreto Legislativo $1 / 2007$, de 16 de noviembre, por el que se aprueba el texto refundido de la Ley General para la Defensa de los Consumidores y Usuarios y otras leyes complementarias, 287 Boletin Oficial del Estado, BOE, 30 de noviembre de 2007. Disponible en: http://www.boe.es/ buscar/act.php?id=BOE-A-2007-20555 
pronunciamientos jurisprudenciales sumamente relevantes en esa materia, en las que los juzgadores comunitario y español, concluyeron, entre otras cuestiones y en términos generales, que sí era posible que el juez analizara el contenido del contrato hipotecario y, en ese sentido, declarara la nulidad de las cláusulas abusivas que en él llegase a encontrar.

Así, vale destacar e insistir en que dichas providencias fueron hondamente significativas en España. Tanto que llevaron a la expedición de una serie de normativas ${ }^{9}$ entre las que se puede destacar, para lo que interesa, la Ley 1/2013, del 14 de mayo, modificatoria del régimen ejecutivo hipotecario de la LEC, permitiendo que, bajo medidas durante la contratación y el proceso ejecutivo de créditos hipotecarios, se pudiera declarar por el notario o el juez la nulidad de una cláusula abusiva.

Veamos los detalles más importantes de las sentencias.

\section{La cláusula abusiva en el marco del proceso ejecutivo. El caso Aziz, sentencia del 14 de marzo de 2013 del Tribunal de Justicia de la Unión Europea}

Sin lugar a dudas, el caso Aziz es un hito en materia de cláusulas abusivas en el marco de los créditos hipotecarios. Revela la difícil situación a la que se enfrentaban los jueces españoles cuando afrontaban, en el marco de un proceso ejecutivo, un contrato de crédito de hipoteca sobre el que, observando una cláusula manifiesta de abuso, no les era dable, a la luz del ordenamiento hasta ese momento existente, ejercer acción legal alguna ${ }^{10}$.

9 España, Real Decreto Ley 8 de 2011, de 1 de julio, de medidas de apoyo a los deudores hipotecarios, de control del gasto público y cancelación de deudas con empresas y autónomos contraídas por las entidades locales, de fomento de la actividad empresarial e impulso de la rehabilitación y de simplificación administrativa, 161 Boletín Oficial del Estado, BOE, 7 de julio de 2011. Disponible en: http://www.boe.es/boe/dias/2011/07/07/pdfs/BOE-A-2011-11641. pdf. España, Real Decreto Ley 6 de 2012, de 9 de marzo, de medidas urgentes de protección de deudores hipotecarios sin recursos, 60 Boletín Oficial del Estado, BOE, 10 de marzo de 2012. Disponible en: http://www.boe.es/diario_boe/txt.php?id=BOE-A-2012-3394. España, Real Decreto Ley 27 de 2012, de 15 de noviembre, de medidas urgentes para reforzar la protección a los deudores hipotecarios, 276 Boletín Oficial del Estado, BOE, 16 de noviembre de 2012. Disponible en: http://www.boe.es/diario_boe/txt.php?id=BOE-A-2012-14115

10 Para profundizar sobre el escenario español con respecto al proceso ejecutivo y las dificultades que generaban la protección de los consumidores y las implicaciones del caso Aziz en la jurisprudencia y la contratación en masa en España, Sergio Cámara-Lapuente, ¿De verdad 
Así, ante esa ardua situación, el Juzgado de lo Mercantil No. 3 de Barcelona, liderado por el juez José María Fernández-Seijo, interpuso al amparo del artículo 267 del Tratado de Funcionamiento de la Unión Europea (TFUE) ${ }^{11}$ una cuestión prejudicial a efectos de indagar la interpretación de la Directiva 93/13/CEE del Consejo, del 5 de abril de 1993, sobre las cláusulas abusivas en los contratos celebrados con consumidores, de cara a la legislación española en materia de cláusulas abusivas y el proceso ejecutivo de crédito hipotecario.

En concreto, el Juzgado encontraba dudas en cuanto a la conformidad del Derecho español con el marco jurídico establecido por la Directiva y, en esa línea, preguntó, primero, "si el sistema de ejecución de títulos judiciales sobre bienes hipotecados o pignorados establecido en el artículo 695 y siguientes de la Ley de Enjuiciamiento Civil, con sus limitaciones en cuanto a los motivos de oposición previstos en el ordenamiento procesal español, no sería sino una limitación clara de la tutela del consumidor por cuanto supone formal y materialmente una clara obstaculización al consumidor para el ejercicio de acciones o recursos judiciales que garanticen una tutela efectiva de sus derechos". Y, segundo, que el tribunal explicara el contenido del concepto "desproporción", establecido en el número 1, letra e), del anexo de la Directiva, el cual

puede controlarse el precio de los contratos mediante la normativa de cláusulas abusivas? De la STJUE de 3 junio 2010 (Caja de Madrid, C-484/08) y su impacto aparente y real en la jurisprudencia española a la STS (pleno) de 9 mayo 2013 sobre las cláusulas suelo, 5 Cuadernos de Derecho Transnacional, 2, 209-233 (2013). Disponible en: http://e-revistas.uc3m.es/index. php/CDT/article/view/1815. Tribunal de Justicia de la Unión Europea, Asunto Mohamed Aziz c. Catalunyacaixa, 14 de marzo de 2013. Disponible en: http://curia.europa.eu/juris/document/ document.jsf?text $=\&$ docid $=135024 \&$ pageIndex $=0 \&$ doclang $=$ es $\&$ mode $=1$ st $\&$ dir $=\&$ occ $=$ first $\&$ part $=1 \&$ cid $=447203$

11 "Artículo 267 (antiguo artículo 234 TCE). El Tribunal de Justicia de la Unión Europea será competente para pronunciarse, con carácter prejudicial: a) sobre la interpretación de los Tratados; b) sobre la validez e interpretación de los actos adoptados por las instituciones, órganos u organismos de la Unión.

Cuando se plantee una cuestión de esta naturaleza ante un órgano jurisdiccional de uno de los Estados miembros, dicho órgano podrá pedir al Tribunal que se pronuncie sobre la misma, si estima necesaria una decisión al respecto para poder emitir su fallo.

Cuando se plantee una cuestión de este tipo en un asunto pendiente ante un órgano jurisdiccional nacional, cuyas decisiones no sean susceptibles de ulterior recurso judicial de Derecho interno, dicho órgano estará obligado a someter la cuestión al Tribunal.

Cuando se plantee una cuestión de este tipo en un asunto pendiente ante un órgano jurisdiccional nacional en relación con una persona privada de libertad, el Tribunal de Justicia de la Unión Europea se pronunciará con la mayor brevedad". Unión Europea, Tratado de Funcionamiento de la Unión Europea, TFUE, Roma, 25 de marzo de 1957. Versión consolidada disponible en: http://www.boe.es/buscar/doc.php?id=DOUE-Z-2010-70006 
dispone que son abusivas las "cláusulas que tengan por objeto o por efecto imponer al consumidor que no cumpla sus obligaciones una indemnización desproporcionadamente alta”.

\section{Los presupuestos de hecho}

La situación que llevó a este cuestionamiento fue la siguiente ${ }^{12}$ : Mohamed Aziz, nacional marroquí que trabajaba en España desde diciembre de 1993, suscribió con la entidad bancaria Catalunyacaixa, mediante escritura notarial, un contrato de préstamo con garantía hipotecaria. El inmueble que constituía esa garantía era la vivienda familiar del señor Aziz, su propietario.

El capital prestado por Catalunyacaixa ascendía a 138.000 euros que debían amortizarse en 33 anualidades, con 396 cuotas mensuales, a partir del año 2007. Así, del contrato suscrito se desprenden las siguientes características: i. de acuerdo con la cláusula 6 se establecieron unos intereses de mora anuales del 18,75\% automáticamente devengables respecto de las cantidades no satisfechas a su vencimiento, sin necesidad de realizar ningún tipo de reclamación; ii. a la luz de la cláusula 6bis de dicho contrato, Catalunyacaixa tenía la facultad de declarar exigible la totalidad del préstamo en el caso de que alguno de los plazos pactados venciera sin que el deudor hubiese cumplido su obligación de pago de una parte del capital o de los intereses del préstamo, y; iii. conforme a la cláusula 15 del contrato, relativa al pacto de liquidez, preveía no solo la posibilidad de que Catalunyacaixa recurriera a la ejecución hipotecaria para cobrar una posible deuda, sino también que pudiera presentar directamente a esos efectos la liquidación mediante el certificado oportuno que recogiese la cantidad exigida.

El señor Aziz pagó con regularidad las cuotas mensuales hasta mayo de 2008. Por ello, el 28 de octubre de ese mismo año, Catalunyacaixa acudió a un notario con el fin de que se otorgara acta de determinación de deuda. Así, el notario certificó que de los documentos aportados y del contenido del contrato de préstamo

12 Soledad Rodríguez-SÁnchez-Tabernero, Sentencia del Tribunal de Justicia de la Unión Europea, de 14 de marzo de 2013, asunto C-415/11, Mohamed Aziz c. Catalunyacaixa. Adecuación al Derecho de la UE del procedimiento de ejecución hipotecaria español, 1 Reseñas de Jurisprudencia Civil, Ars Iuris Salmanticensis, Universidad de Salamanca, 227-293, 238 ss. (enero-junio, 2013). Disponible en: revistas.usal.es/index.php/ais/article/download/11545/11964 
se derivaba que la liquidación de la deuda ascendía a 139.764,76 euros, lo que correspondía a las mensualidades no satisfechas, más los intereses ordinarios y los intereses de mora.

Tras requerir infructuosamente al señor Aziz el pago de lo debido, Catalunyacaixa inició el 11 de marzo de 2009, ante el Juzgado de Primera Instancia No. 5 de Martorell, un procedimiento de ejecución contra el interesado, reclamándole la cantidad de 139.674,02 euros. Ante el no pago por parte del demando, el Juzgado ordenó la ejecución el 15 de diciembre de 2009.

Así las cosas, el 20 de julio de 2010 se celebró una subasta pública para proceder a la venta del inmueble, sin que se presentara ninguna oferta. De este modo, con arreglo a lo dispuesto en la LEC, el Juzgado de Primera Instancia No. 5 de Martorell admitió que el bien se adjudicara en el 50\% de su valor. Dicho Juzgado también señaló el 20 de enero de 2011 como la fecha en que debía producirse la transmisión de la posesión al adjudicatario. En consecuencia, el señor Aziz fue expulsado de su vivienda.

Sin embargo, poco antes de que eso ocurriera, el 11 de enero de 2011, el señor Aziz presentó demanda en un proceso declarativo ante el Juzgado de lo Mercantil No. 3 de Barcelona, solicitando que se anulara la cláusula 15 del contrato de préstamo hipotecario por estimarla abusiva y, de esta manera, se declarara la nulidad del procedimiento de ejecución.

Ante esta circunstancia, el Juzgado de lo Mercantil No. 3 de Barcelona elevó la cuestión prejudicial manifestando que "... si, a efectos de la ejecución forzosa, el acreedor opta por el procedimiento de ejecución hipotecaria, las posibilidades de alegar el carácter abusivo de alguna de las cláusulas del contrato de préstamo son muy limitadas, ya que quedan postergadas a un procedimiento declarativo posterior, que no tiene efecto suspensivo. El órgano jurisdiccional remitente consideró que, por este motivo, resulta muy complicado para un juez español garantizar una protección eficaz al consumidor en dicho procedimiento de ejecución hipotecaria y en el correspondiente proceso declarativo".

Por otra parte, el Juzgado de lo Mercantil No. 3 de Barcelona estimó que la solución del litigio principal planteaba otras cuestiones, a saber: La interpretación del concepto de "cláusulas que tengan por objeto o por efecto imponer al consumidor que no cumpla sus 
obligaciones una indemnización desproporcionadamente alta", contemplado en el número 1, letra e), del anexo de la Directiva, y el de "cláusulas que tengan por objeto o por efecto suprimir u obstaculizar el ejercicio de acciones judiciales o de recursos por parte del consumidor", previsto en el número 1, letra q), de dicho anexo.

En esa línea, sostuvo ese despacho, no está claro que las cláusulas relativas al vencimiento anticipado en contratos de larga duración, a la fijación de intereses de mora y a la determinación unilateral por parte del prestamista de los mecanismos de liquidación de la totalidad de la deuda, sean compatibles con las disposiciones del anexo de la Directiva.

\section{Las consideraciones frente a las cuestiones prejudiciales}

Así, sobre la primera problemática jurídica el Tribunal de Justicia de la Unión Europea consideró “... que el sistema de protección que establece la Directiva se basa en la idea de que el consumidor se halla en situación de inferioridad respecto al profesional, en lo referido tanto a la capacidad de negociación como al nivel de información (...). Habida cuenta de esta situación de inferioridad, el artículo 6, apartado 1, de la Directiva dispone que las cláusulas abusivas no vincularán al consumidor. Según se desprende de la jurisprudencia, se trata de una disposición imperativa que pretende reemplazar el equilibrio formal que el contrato establece entre los derechos y obligaciones de las partes por un equilibrio real que pueda restablecer la igualdad entre estas (...). En este contexto, el Tribunal de Justicia ha subrayado ya en varias ocasiones que el juez nacional deberá apreciar de oficio el carácter abusivo de una cláusula contractual incluida en el ámbito de aplicación de la Directiva y, de este modo, subsanar el desequilibrio que existe entre el consumidor y el profesional, tan pronto como disponga de los elementos de hecho $y$ de Derecho necesarios para ello (...)".

Así, frente al caso concreto adujo que un régimen procesal como el español, en el que no se permite que el juez declarativo, que conoce de la existencia de una cláusula abusiva de un título ejecutivo, adopte medidas cautelares a efectos de suspender la ejecución hipotecaria que se adelanta contra el deudor, o que el juez de ejecución no pueda realizar una evaluación de los clausulados 
del contrato hipotecario, puede menoscabar los derechos de los consumidores y, en ese sentido, la efectiva protección que pretende garantizar la Directiva.

En efecto, la máxima corporación judicial europea explicó que una consagración de ese tipo solo permite garantizar al consumidor una protección posterior, meramente indemnizatoria, que no preventiva, la cual resulta incompleta e insuficiente. De este modo, no constituye un medio adecuado y eficaz para que cese el uso de dicha cláusula, y contraría lo establecido en el artículo 7, apartado 1, de la Directiva 93/13. Máxime si se está frente a un caso en el que el objeto de la garantía hipotecaria es la vivienda familiar del consumidor perjudicado. Allí, el pago de una indemnización por daños y perjuicios posterior no es un remedio adecuado para evitar la pérdida definitiva e irreversible del hogar, pues hay alternativas y herramientas de orden legal que pueden prevenirlo.

Por ello, el Tribunal de Justicia Europeo declaró que la normativa española controvertida no se ajustaba al principio de efectividad, en la medida en que hace imposible o excesivamente difícil, en los procedimientos de ejecución hipotecaria en los que los consumidores son parte demandada, aplicar la protección que la Directiva pretendía conferir a estos últimos.

Así las cosas, con respecto al primer interrogante, el Tribunal concluyó que "la Directiva 93/13/CEE del Consejo, de 5 de abril de 1993, sobre las cláusulas abusivas en los contratos celebrados con consumidores, debe interpretarse en el sentido de que se opone a una normativa de un Estado miembro, como la controvertida en el litigio principal que, al mismo tiempo que no prevé, en el marco del procedimiento de ejecución hipotecaria, la posibilidad de formular motivos de oposición basados en el carácter abusivo de una cláusula contractual que constituye el fundamento del título ejecutivo, no permite que el juez que conozca del proceso declarativo, competente para apreciar el carácter abusivo de esa cláusula, adopte medidas cautelares, entre ellas, en particular, la suspensión del procedimiento de ejecución hipotecaria, cuando acordar tales medidas sea necesario para garantizar la plena eficacia de su decisión final" (resaltado propio).

Ahora, en lo que respecta a la segunda cuestión, explicó el Tribunal que "El artículo 3, apartado 1, de la Directiva 93/13 debe interpretarse en el sentido de que: _el concepto de \desequilibrio 
importante区 en detrimento del consumidor debe apreciarse mediante un análisis de las normas nacionales aplicables a falta de acuerdo entre las partes, para determinar si —y, en su caso, en qué medida-el contrato deja al consumidor en una situación jurídica menos favorable que la prevista por el Derecho nacional vigente. Asimismo, resulta pertinente a estos efectos llevar a cabo un examen de la situación jurídica en la que se encuentra dicho consumidor en función de los medios de que dispone con arreglo a la normativa nacional para que cese el uso de cláusulas abusivas; - para determinar si se causa el desequilibrio 囚pese a las exigencias de la buena fe区, debe comprobarse si el profesional, tratando de manera leal y equitativa con el consumidor, podía estimar razonablemente que este aceptaría la cláusula en cuestión en el marco de una negociación individual. El artículo 3, apartado 3, de la Directiva 93/13 debe interpretarse en el sentido de que el anexo al que remite esa disposición solo contiene una lista indicativa y no exhaustiva de cláusulas que pueden ser declaradas abusivas" (resaltado propio).

\section{Las cláusulas "suelo": ¿abusivas o ambiguas? \\ La sentencia del 9 de mayo de 2013 de la Sala Civil del Tribunal Supremo Español}

La llamada cláusula suelo, también conocida como suelo hipotecario, es una cláusula contractual que se tornó típica en los contratos de crédito hipotecario españoles, mediante la cual se establece un mínimo de pago en las cuotas del préstamo, aunque los intereses variables acordados con la entidad financiera bajen o estén por debajo de ese mínimo.

Así, otra de las providencias relevantes en materia de cláusulas abusivas, es la famosa sentencia del 9 de mayo de 2013, de la Sala Civil de Tribunal Supremo español, la cual, precisamente al amparo de las consideraciones del caso Aziz del Tribunal Europeo, efectuó un examen exhaustivo del citado tipo de cláusulas, con el objetivo de esclarecer si eran o no abusivas.

Con ese lineamiento, la Sala Civil analizó las cláusulas suelo de créditos hipotecarios de las entidades BBVA (Banco Bilbao Vizcaya Argentaria), NCG Banco (hoy ABANCA Corporación Bancaria, S.A.) y Cajamar (Caja Rural, Cajas Rurales Unidas, So- 
ciedad Cooperativa de Crédito) en España, para sostener que estas cláusulas eran nulas por falta de transparencia y que, para concluir algo semejante en situaciones similares, habría que analizar cada caso concreto.

Para llegar a esa consideración, el Tribunal Supremo empezó por plantear que debía morigerarse, en línea con lo establecido en el caso Aziz, la forma en que se surten los procesos ejecutivos hipotecarios. De este modo expresó: “... en la medida en que sea necesario para lograr la eficacia del Derecho de la Unión, en los supuestos de cláusulas abusivas, los tribunales deben atemperar las clásicas rigideces del proceso, de tal forma que, en el análisis de la eventual abusividad de las cláusulas cuya declaración de nulidad fue interesada, no es preciso que nos ajustemos formalmente a la estructura de los recursos. Tampoco es preciso que el fallo se ajuste exactamente al suplico de la demanda, siempre que las partes hayan tenido la oportunidad de ser oídas sobre los argumentos determinantes de la calificación de las cláusulas como abusivas".

Explicó, además, en qué consisten las condiciones predispuestas y el hecho de que su existencia no acarree necesariamente su ilicitud $^{13}$.

13 Al respecto, el Tribunal Supremo sostuvo: “a) La prestación del consentimiento a una cláusula predispuesta debe calificarse como impuesta por el empresario cuando el consumidor no puede influir en su supresión o en su contenido, de tal forma que o se adhiere y consiente contratar con dicha cláusula o debe renunciar a contratar. b) No puede equipararse la negociación con la posibilidad real de escoger entre pluralidad de ofertas de contrato sometidas todas ellas a condiciones generales de contratación aunque varias de ellas procedan del mismo empresario. c) Tampoco equivale a negociación individual susceptible de eliminar la condición de cláusula no negociada individualmente, la posibilidad, cuando menos teórica, de escoger entre diferentes ofertas de distintos empresarios. d) La carga de la prueba de que una cláusula pre redactada no está destinada a ser incluida en pluralidad de ofertas de contrato dirigidos por un empresario o profesional a los consumidores, recae sobre el empresario. Finalmente, a fin de evitar equívocos, añadiremos que la imposición de cláusulas o condiciones generales por el empresario a los consumidores, no comporta su ilicitud. Se trata de un mecanismo de contratar propio de la contratación en masa, ante la imposibilidad y los costes de mantener diálogos individualizados o, como afirma la STS 406/2012, de 18 de junio, RC 46/2010, se trata de un fenómeno que \comporta en la actualidad un auténtico \modo de contratar $\bigotimes$, diferenciable de la contratación por negociación, con un régimen y presupuesto causal propio y especifico区. De tal forma, que ni siquiera cuando la totalidad del contrato hubiera sido predispuesto por una de las partes, ya que, dentro de los límites fijados por el legislador, la libertad de empresa permite al empresario diseñar los productos y servicios que ofrece y en qué condiciones, afirmando la STS 99/2009, de 4 de marzo, RC 535/2004, que 区la calificación como contrato de adhesión [...] no provoca por ello mismo su nulidad®”. Tribunal Supremo de España, Sala Civil, Sentencia 241, 9 de mayo de 2013, magistrado ponente Rafael Gimeno-Bayon Cobos. Disponible en: http://www.uclm.es/Actividades/repositorio/pdf/doc_4591_6079.pdf. Tribunal Supremo de España, Sala Civil, Sentencia 406/2012, de 18 de junio de 2012, Recurso 46/2010, magistrado ponente Francisco Javier Orduña-Moreno. Disponible en: http://portaljuridico.lexnova.es/ 
Ahora, en relación con las cláusulas suelo, el Tribunal encontró que son un elemento perteneciente al objeto principal del contrato. Por ese motivo, y considerando, primero, que la Directiva 93/13 indica que "... la apreciación del carácter abusivo no debe referirse ni a cláusulas que describan el objeto principal del contrato ni a la relación calidad/precio de la mercancía o de la prestación; que en la apreciación del carácter abusivo de otras cláusulas podrán tenerse en cuenta, no obstante, el objeto principal del contrato y la relación calidad/precio; que de ello se desprende, entre otras cosas, que en los casos de contratos de seguros las cláusulas que definen o delimitan claramente el riesgo asegurado y el compromiso del asegurador no son objeto de dicha apreciación, ya que dichas limitaciones se tienen en cuenta en el cálculo de la prima abonada por el consumidor”. Y que, segundo, al tenor literal del artículo 4.2 de la citada Directiva: "la apreciación del carácter abusivo de las cláusulas no se referirá a la definición del objeto principal del contrato ni a la adecuación entre precio y retribución, por una parte, ni a los servicios o bienes que hayan de proporcionarse como contrapartida, por otra, siempre que dichas cláusulas se redacten de manera clara y comprensible", el Tribunal concluyó que las cláusulas suelo describen y definen el objeto principal del contrato de préstamo de crédito y que, en esa línea, no puede examinarse la abusividad de su contenido.

Sin embargo, a la luz del tenor del artículo 5.5 de la Ley $7 / 1998^{14}$, relativo a los requisitos de incorporación de las referidas condiciones, "la redacción de las cláusulas generales deberá ajustarse a los criterios de transparencia, claridad, concreción y sencillez". En consecuencia, el Tribunal explicó que sí cabe realizar un control de transparencia a efectos de esclarecer su licitud.

Así las cosas, y tras el estudio propuesto, el Tribunal concluyó que las cláusulas suelo analizadas no son transparentes por las siguientes razones, “a) Falta información suficientemente clara

jurisprudencia/JURIDICO/147801/sentencia-ts-406-2012-sala-1-de-18-de-junio-prestamohipotecario-usura-intereses. Tribunal Supremo de España, Sala Civil, Sentencia 99/2009, de 4 de marzo de 2009, Recurso 535/2004, magistrado ponente Encarnación Roca-Trías. Disponible en: http://supremo.vlex.es/vid/concesion-automoviles-interpretacion-adhesion-57206818. LuIs Díez-Picazo, Manuel Clavero-Arévalo \& José María Abascal-Zamora, Las condiciones generales de la contratación y cláusulas abusivas (Ediciones Civitas, Madrid, 1996).

14 España, Ley 7/1998, de 13 de abril, sobre condiciones generales de la contratación, 89 Boletín Oficial del Estado, BOE, 14 de abril de 1998. Disponible en: http://www.boe.es/buscar/act. php?id=BOE-A-1998-8789 
de que se trata de un elemento definitorio del objeto principal del contrato. b) Se insertan de forma conjunta con las cláusulas techo y como aparente contraprestación de las mismas. c) No existen simulaciones de escenarios diversos relacionados con el comportamiento razonablemente previsible del tipo de interés en el momento de contratar. d) No hay información previa clara y comprensible sobre el coste comparativo con otras modalidades de préstamo de la propia entidad - caso de existir-o advertencia de que al concreto perfil de cliente no se le ofertan las mismas. e) En el caso de las utilizadas por el BBVA, se ubican entre una abrumadora cantidad de datos entre los que quedan enmascaradas y que diluyen la atención del consumidor".

De este modo, la corporación manifestó que "las cláusulas suelo son lícitas siempre que su transparencia permita al consumidor identificar la cláusula como definidora del objeto principal del contrato y conocer el real reparto de riesgos de la variabilidad de los tipos. Es necesario que esté perfectamente informado del comportamiento previsible del índice de referencia cuando menos a corto plazo, de tal forma que cuando el suelo estipulado lo haga previsible, esté informado de que lo estipulado es un préstamo a interés fijo mínimo, en el que las variaciones del tipo de referencia a la baja probablemente no repercutirán o lo harán de forma imperceptible en su beneficio".

Con todo hasta ahí, y para el caso puesto a consideración del Tribunal Supremo, la máxima Corporación decidió: i. condenar a las demandadas a eliminar de sus contratos las cláusulas suelo objeto de examen en la forma y modo en que se utilizan; ii. condenar a las demandadas a abstenerse de utilizarlas en la forma y modo en que se venían utilizando, y; iii. los contratos vigentes seguirán siendo obligatorios para las partes en los mismos términos. Eso sí, sin las cláusulas abusivas.

\section{Algunas consideraciones sobre las providencias españolas}

Como se ha podido observar, la solución española a la problemática de la declaratoria de cláusulas abusivas en los contratos de crédito hipotecario en el marco de procedimientos ejecutivos, se debió 
gracias, primero, a un importante activismo judicial y, no menos trascendental y en segundo lugar, a los recursos normativos de orden superior - constitucional y comunitario para el caso español—que llevaron a una mejor garantía de los derechos del consumidor en general, y financiero en particular.

En efecto, a partir de reglas generales, en especial de orden superior, relacionadas con derechos fundamentales, aunadas a una vertebral pro actividad de los jueces, se ha logrado ofrecer una mejor protección de los derechos de los consumidores de créditos hipotecarios, quienes no encontraban, en el ordenamiento jurídico sustantivo y procesal, hasta el momento existente, una garantía idónea y eficaz frente a la crisis económica y social que vivía el país.

Justamente, la relación interpretativa — si se quiere, integradora - de la normativa civil y de consumo — sustancial y procesal- con el ordenamiento constitucional y comunitario, llevó a una aplicación mucho más flexible de los presupuestos procesales que reglaban el procedimiento ejecutivo hipotecario para que, en él, se pudiera también declarar la existencia de cláusulas abusivas, ambiguas o no trasparentes.

Se identifica así, de manera específica, un fenómeno general que ha venido experimentando de tiempo atrás el derecho civil: su socialización o "constitucionalización". En efecto, el autor español Eugenio Llamas-Pombo, al describir el citado fenómeno, sostiene que ante la crisis de la distinción entre derecho público y derecho privado, aunado a la importancia que han adquirido las constituciones, se ha surtido un proceso en el que el derecho civil, a diferencia del consagrado en las codificaciones, ya no es un puro ordenamiento de los particulares, centrado en los intereses individuales, opuestos al derecho público, sino un régimen normativo sensible a los intereses colectivos, desarrollador de los derechos fundamentales consagrados en la Carta Política ${ }^{15}$.

Así, la socialización del derecho civil no debe comprenderse como una diatriba en contra de los presupuestos clásicos que sostienen esa rama de la ciencia jurídica. Todo lo contrario: supone

15 Eugenio Llamas-Pombo, Orientaciones sobre el concepto y el método del derecho civil, $114 \mathrm{ss.}$ (Editorial Pontificia Universidad Javeriana, Bogotá, 2009). Miguel Pasquau-Liaño, Código civil y ordenamiento jurídico. Otra reflexión sobre el devenir del derecho civil (Editorial Comares, Granada, 1994). 
desprenderse del viejo individualismo, característico del clásico derecho civil, para dar lugar a los intereses sociales de cara a las realidades socioeconómicas que afectan a las personas. Ello implica, entre otras cuestiones, proteger a los más débiles - consumidores, usuarios, víctimas de daños y perjuicios, etc. - y los valores y derechos colectivos imperantes — la igualdad, la propiedad y su función ambiental y social, el buen nombre, el honor, etc.-.

En ese sentido, en el ámbito legal español, se destaca la sentencia del Tribunal Constitucional 18/1984, del 7 de febrero, en el que esa corporación resalta la importancia de relativizar el derecho a la luz de la Constitución y los presupuestos que mandan al Estado social de derecho ${ }^{16}$.

Precisamente, uno de los mecanismos en los que se manifiesta la socialización del derecho civil es mediante la intervención directa de la administración pública en las relaciones privadas, en especial, para lo que interesa y como se ha visto, por medio de las providencias judiciales - una de las tantas maneras de intervencionismo-.

Debe destacarse que, como afirma Fernández-Seijo, si bien la eclosión de litigios es sin duda positiva, en la medida en que evidencia que los ciudadanos recuperan su confianza en los tribunales y permite, aunque sea temporalmente, mitigar las devastadoras consecuencias de la crisis económica en muchas familias, la solución para los problemas estructurales de la contratación con consumidores no puede ser siempre la judicialización del conflicto, ya que implicaría un elevado y cuantioso desgaste del aparato judicial, además de hacerlo mucho más lento y afectar, hasta cierto punto, la seguridad jurídica. De ahí que, aparte de la judicialización, deban analizarse alternativas de prevención en el marco de las normativas sustantivas y procesales que logren, ante la existencia de problemáticas como las planteadas en el caso Aziz, que el juzgador pueda solucionar de forma célere el litigio sobre las cláusulas abusivas ${ }^{17}$.

16 Tribunal Constitucional Español, Sala Primera, Sentencia 18 de 1984, 7 de febrero de 1984. Disponible en: http://www.tribunalconstitucional.es/es/jurisprudencia/Paginas/Sentencia. aspx?cod=16897, http://hj.tribunalconstitucional.es/HJ/es/Resolucion/Show/271. (7 febrero, 1984).

17 José María Fernández-Seijo, Un año después de la Sentencia del caso Aziz, 286 Revista Món Jurídic, Revista del Ilustre Colegio de Abogados de Barcelona, 16-17 (2014). Disponible en: http://dialnet.unirioja.es/servlet/articulo?codigo $=4680285$ 
Sin perjuicio de ello, con fundamento hasta lo aquí visto, puede sostenerse con claridad meridiana, que la constitucionalización o socialización del derecho civil, identificada en el caso de las cláusulas abusivas en los contratos de crédito hipotecario en España bajo el activismo judicial, la relativización del derecho civil y la incorporación de elementos externos a él, ha sido la mejor forma para aclimatar el ordenamiento privado a las realidades socioeconómicas cambiantes y críticas en ciertos supuestos.

Ahora bien, este carácter no ha sido exclusivo del escenario jurídico español. Se verá cómo en Colombia, a partir de la crisis hipotecaria del UPAC (Unidad de Poder Adquisitivo Constante), también se ha previsto un fenómeno similar en el que, gracias a la pro actividad judicial y al amparo de los derechos fundamentales de orden constitucional, se ha protegido a los consumidores colombianos y se han generado reglas mucho más beneficiosas para ellos. Además, y aunque no es materia de análisis, sí debe destacarse que hoy vemos los frutos de la socialización del derecho civil en campos tan diversos como el de la responsabilidad contractual y extracontractual. La sentencia SC102827-2014, de la Sala de Casación Civil de la Corte Suprema de Justicia colombiana, es prueba fehaciente de ello ${ }^{18}$.

\section{B. El contexto de Colombia frente a una crisis hipotecaria}

Colombia tuvo que afrontar una fuerte crisis financiera entre los años 1998 y 2001, la cual produjo un grave impacto en los créditos hipotecarios otorgados. Para analizar la forma en que el país reaccionó ante la crisis, se examinarán sus causas y las respuestas frente a la situación, en particular en materia hipotecaria.

\section{Causas de la crisis}

Entre las principales causas de la crisis financiera que atravesó Colombia a finales de los años noventa se encuentran la suspensión de flujos de capital externo, la liberalización del sistema financiero, el crecimiento irresponsable de los créditos, la revaluación, el

18 Corte Suprema de Justicia de Colombia, Sala de Casación Civil, Sentencia SC 102827 (2014). 
aumento de las tasas de interés y la falta de regulación en el sector hipotecario, entre otras ${ }^{19}$.

Durante estos años se presentaron reformas que buscaban liberalizar el sistema financiero para promover la competencia, mejorar la eficiencia y dar mayor libertad al manejo de operaciones y $\operatorname{tasas}^{20}$ que se reflejaron en varias leyes. La Ley 45 de 1990 y la Ley 35 de 1993 reestructuraron el sistema financiero y la Ley 09 de $1991^{21}$ tuvo como uno de sus principales objetivos el de estimular en el país la inversión de capitales provenientes del exterior. Se les permitió a otras entidades financieras ofrecer cuentas de ahorro. Se ató la corrección monetaria a la tasa de interés de captación para que los bancos hipotecarios pudieran competir con otras entidades financieras ${ }^{22}$.

Se presentó entonces en la década de los noventa, un gran aumento del crédito pero sin un seguimiento de la calidad de la cartera. Se dependía en gran medida de la entrada de capitales al país; sin embargo, este flujo se frenó, lo que además de ocasionar una fuerte reducción en el PIB, provocó un alza de las tasas de interés.

Con ocasión de eventos internacionales, el Banco de la República trató de defender la tasa de cambio que subió de forma exorbitante.

19 Miguel Arango, Evolución y crisis del sistema financiero colombiano (Serie Estudios y Perspectivas, 11, Ed. Cepal-Naciones Unidas, Bogotá, junio de 2006). Disponible en: http:// repositorio.cepal.org/bitstream/handle/11362/4809/S0600444_es.pdf?sequence $=1$

20 Sergio Clavijo, Alejandro Vera, María P. Salcedo, Jennifer Carvajal, Arturo Galindo \& Francesca Castellani, El crédito hipotecario en Colombia: Evaluación del impacto regulatorio pos-crisis (Working paper, investigación realizada por ANIF (Asociación Nacional de Instituciones Financieras) para el BID (Banco Interamericano de Desarrollo), mayo de 2011). Disponible en: http://anif.co/sites/default/files/uploads/Anif-BID0511.pdf

21 Ley 45 de 1990, por la cual se expiden normas en materia de intermediación financiera, se regula la actividad aseguradora, se conceden unas facultades y se dictan otras disposiciones, 39.607 Diario Oficial, 19 de diciembre de 1990. Disponible en: http://www.cancilleria.gov.co/ sites/default/files/Normograma/docs/ley_0045_1990.htm. Ley 09 de 1991, por la cual se dictan normas generales a las que deberá sujetarse el Gobierno Nacional para regular los cambios internacionales y se adoptan medidas complementarias, 39.634 Diario Oficial, 17 de enero de 1991. Disponible en: http://www.banrep.gov.co/sites/default/files/paginas/LEY09DE1991CONHIPERVINCULOS-1.pdf. Ley 35 de 1993, por la cual se dictan normas generales y se señalan en ellas los objetivos y criterios a los cuales debe sujetarse el Gobierno Nacional para regular las actividades financiera, bursátil y aseguradora y cualquier otra relacionada con el manejo, aprovechamiento e inversión de recursos captados del público y se dictan otras disposiciones en materia financiera y aseguradora, 40.710 Diario Oficial, 5 de enero de 1993. Disponible en: http://www.secretariasenado.gov.co/senado/basedoc/ley_0035_1993.html

22 Leonardo Villar-Gómez, David M. Salamanca-Rojas \& Andrés Murcia-Pabón, Crédito, represión financiera y flujos de capitales en Colombia: 1974-2003, 55 Desarrollo y Sociedad, Universidad de los Andes, 167-209 (2005). Disponible en: http://www.researchgate.net/publication/4747000_Crdito_represin_financiera_y_flujos_de_capitales_en_Colombia_1974-2003 
Aunque inicialmente se creyó que la crisis hipotecaria asiática de 1997 sería una cuestión focalizada, sus repercusiones fueron globa$\operatorname{les}^{23}$. En Colombia, los saldos hipotecarios se dispararon, el ingreso y el precio de los bienes raíces cayeron ${ }^{24}$. La caída intempestiva de las fuentes de fondeo deterioró la capacidad de pago de los sujetos que tuvieron que entregar en dación de pago sus bienes inmuebles, lo que llevó a la quiebra a muchas entidades financieras ${ }^{25}$. Las obligaciones de los deudores hipotecarios se elevaron cuando justamente aumentaba el desempleo y se reducían los ingresos de las personas.

La liberalización del sistema financiero tuvo un fuerte impacto en las entidades hipotecarias que eran las encargadas de otorgar los préstamos de largo plazo para construcción y compra de vivienda, pues se eliminó el cuasi monopolio que tenían en el mercado de ahorros, se eliminaron las facilidades que tenían con la banca central y aumentó el riesgo de liquidez al aumentar la competencia ${ }^{26}$.

\section{Reacción frente a la crisis}

Para enfrentar la crisis financiera, el gobierno colombiano y el Banco de la República implantaron diversas reformas. La Superintendencia Financiera diseñó un nuevo sistema de administración del riesgo para que las entidades financieras lograran mantener un nivel adecuado de capital y provisiones ${ }^{27}$.

Con el Decreto 2330 del 16 de noviembre de 1998, el gobierno declaró el estado de emergencia económica y social en Colombia.

23 Sobre esta crisis, Juan José Echavarría \& María Angélica Arbeláez, Tasa de cambio y crecimiento económico (2003). Disponible en: http://www.banrep.gov.co/docum/ftp/borra338. pdf.B http://www.banrep.gov.co/sites/default/files/publicaciones/pdfs/borra338.pdf

24 Leonardo Villar-Gómez, David M. Salamanca-Rojas \& Andrés Murcia-Pabón, Crédito, represión financiera y flujos de capitales en Colombia: 1974-2003, 55 Desarrollo y Sociedad, Universidad de los Andes, 167-209 (2005). Disponible en: http://www.researchgate.net/publication/4747000_Crdito_represin_financiera_y_flujos_de_capitales_en_Colombia_1974-2003

25 Fondo de Garantías de Instituciones Financieras, Fogafin, Crisis financieras sistémicas en Colombia y contraste con el escenario actual, No. 2 (marzo de 2012). Disponible en: https:// www.fogafin.gov.co/default/imagenes/file/Informacion $\% 20 \mathrm{al} \% 20$ Ciudadano/Publicaciones/ Crisis $\% 20$ financieras $\% 20$ sistemicas $\% 20$ en $\% 20$ Colombia $\% 20 \mathrm{y} \% 20$ Contraste $\% 20$ con $\% 20$ el $\% 20$ escenario $\% 20$ actual.pdf

26 José Darío URibe, Banco de la República, Algunas lecciones relevantes aprendidas de la crisis financiera colombiana de 1998-1999. Disponible en: http://www.banrep.gov.co/sites/default/ files/publicaciones/archivos/jdu_may_2008.pdf

27 José Eduardo Gómez-González, Luisa Silva, Sergio Restrepo \& Mauricio Salazar, Flujos de capital y fragilidad financiera en Colombia, 30 Ensayos sobre Política Económica, 69, 67-109 (2012). Disponible en: http://www.scielo.org.co/scielo.php?script=sci_arttext\&pid=S0120$44832012000300003 \& \operatorname{lng}=$ en\&nrm=iso\&tlng=es 
Con este Decreto y el Decreto 2331 de 1998 se crearon mecanismos institucionales y de financiación para aliviar la crisis y el deterioro hipotecario.

Además de las respuestas legales, la reacción de la Corte Constitucional fue fundamental en esta crisis. Por un lado, la Corte Constitucional validó gran parte del contenido de los decretos, aunque varió el alcance de algunas de sus medidas ${ }^{28}$. Por otro lado, con la sentencia C-700 de 1999, la Corte declaró inexequibles todos los artículos del Estatuto Orgánico del Sistema Financiero que desarrollaban el sistema UPAC. Lo anterior llevó a la expedición de la Ley 546 de 1999, con la cual el Congreso reglamentó el sector hipotecario, se reemplazó el UPAC por la UVR para atar las deudas exclusivamente al IPC, se exigieron cuotas iniciales de mínimo el $30 \%$, se creó el Fondo de Reserva para la Estabilización de la Cartera Hipotecaria para facilitar la financiación de vivienda a largo plazo. La sentencia C-747 de 1999 declaró la inconstitucionalidad de la capitalización de intereses en los créditos de vivienda. Estos cambios fueron muy positivos pues con la UVR se buscó evitar que hacia el futuro los deudores se enfrentaran a unas tasas diferentes a las esperadas. Con la regulación de los sistemas de amortización y la exigencia de al menos el $30 \%$ en la cuota inicial, se podían evitar en muchos casos sistemas de pago insostenibles en el tiempo. Sin embargo, este activismo judicial fue muy controvertido ${ }^{29}$.

Algunos consideraron que las medidas adoptadas en reacción a la crisis fueron inadecuadas y peligrosas para la seguridad jurídica; para la ANIF, por ejemplo, las principales secuelas de la crisis hipotecaria colombiana en razón de las respuestas judiciales y legales del momento son ${ }^{30}$ :

28 Por ejemplo, la sentencia C-136-99 declaró exequible el "impuesto del dos por mil" pero condicionó la norma "en el sentido de que tampoco son sujetos pasivos del impuesto los tesoros de las entidades territoriales ni los fondos que administran contribuciones parafiscales, $y$ en el de que la no sujeción del Banco de la República al tributo únicamente es constitucional en la medida en que las operaciones correspondientes se efectúen en interés del propio Banco Central, y de ninguna manera en interés de terceros, de establecimientos de crédito o de entidades financieras". Corte Constitucional de Colombia, Sentencia C-136-99, 4 de marzo de 1999, magistrado ponente José Gregorio Hernández. Disponible en: http://www.corteconstitucional.gov.co/relatoria/1999/c-136-99.htm

29 Sobre el papel, en general, del juez constitucional en las políticas públicas, Manuel Fernando Quinche-Ramírez \& JuAN CAMILO Rivera-Rugeles, El control judicial de las politicas públicas como instrumento de inclusión de los derechos humanos, 121 Vniversitas, 113-137 (2010). Disponible en: http://www.redalyc.org/pdf/825/82518988005.pdf

30 Sergio Clavijo, Alejandro Vera, María P. Salcedo, Jennifer Carvajal, Arturo Galindo 
- El Impuesto a los Movimientos Financieros (3 x 1.000 que luego se convirtió en 3 x 1.000 y finalmente en el 4 x 1.000).

- El contencioso jurídico de los pleitos hipotecarios que generan inseguridad tanto para los usuarios como para el sector financiero.

- El estancamiento financiero.

El Banco Mundial también manifestó una posición crítica de las respuestas legislativas a la crisis, al considerar que el criterio de la legislación de finales de los noventa que regulaba la insolvencia, parecía proteger a ultranza a los deudores que estaban en dificultades financieras en perjuicio de los intereses de los acreedores ${ }^{31}$.

Otros, por el contrario, celebraron las medidas mencionadas, considerando que lejos de una intervención indebida, la Corte reaccionó para solucionar los problemas que generados por la vulneración de los derechos de los ciudadanos ante la incompetencia de las entidades que debían resolverlos ${ }^{32}$.

\section{La situación de las cláusulas abusivas en EL DERECHO CONTRACTUAL COLOMBIANO}

En materia de créditos hipotecarios, es posible revisar si hay o no abusividad en las cláusulas o prácticas contractuales. Hay incluso una legislación especial de protección al consumidor financiero, además de la protección general del Estatuto del Consumidor ${ }^{33}$.

\& Francesca Castellani, El crédito hipotecario en Colombia: Evaluación del impacto regulatorio pos-crisis (Working paper, investigación realizada por ANIF (Asociación Nacional de Instituciones Financieras) para el BID (Banco Interamericano de Desarrollo), mayo de 2011). Disponible en: http://anif.co/sites/default/files/uploads/Anif-BID0511.pdf

31 Adolfo Roulllon, Colombia: Derechos de Crédito y Procesos Concursales (Working paper 70442, Banco Mundial, Grupo de Finanzas, Sector Privado e Infraestructura, Región de América Latina y el Caribe, 2006). Disponible en: http://documents.worldbank.org/curated/ en/2006/05/16500605/colombia-derechos-de-crédito-y-procesos-concursales

32 Juan Carlos Henao-PÉRez, El juez constitucional: un actor de las políticas públicas, 15 Revista de Economía Institucional, 29, 67-102, 99 (2013). Disponible en: http://www.economiainstitucional.com/esp/vinculos/pdf/No29/jhenao29.pdf

33 Ley 1328 de 2009, por la cual se dictan normas en materia financiera, de seguros, del mercado de valores y otras disposiciones, 47.411 Diario Oficial, 15 de julio de 2009. Disponible en: http://www.secretariasenado.gov.co/senado/basedoc/ley_1328_2009.html. Ley 1480 de 2011, por medio de la cual se expide el Estatuto del Consumidor y se dictan otras disposiciones, 48.220 Diario Oficial, 12 de octubre de 2011. Disponible en: http://www.secretariasenado.gov. co/senado/basedoc/ley_1480_2011.html 


\section{A. Protección general en el ordenamiento jurídico colombiano frente a las cláusulas abusivas}

Tanto la Constitución como la ley sancionan el abuso del derecho y, por consiguiente, las cláusulas abusivas que se establezcan en los contratos.

\section{1. Protección constitucional}

La noción del abuso del derecho fue introducida en Colombia por la Corte Suprema de Justicia en los años treinta del siglo $\mathrm{XX}^{34} \mathrm{y}$ fue posteriormente incorporada en la Constitución Política de 1991 en su artículo 95, en virtud del cual las personas deben "respetar los derechos ajenos y no abusar de los propios".

Ha sido frecuente en Colombia y en otros sistemas utilizar los derechos humanos y los derechos constitucionales para proteger a los más débiles que están en una situación de vulnerabilidad particular. En materia de derecho privado, en particular en el ámbito contractual, aunque la normatividad que le es propia cuenta con herramientas que en la lógica de su área específica deberían otorgar esta protección, como el principio del no abuso del derecho, es usual encontrar el apoyo constitucional inmerso en situaciones contractuales.

Dado que el principio del no abuso del derecho y el principio de la buena fe tienen origen en el derecho privado y fueron posteriormente consagrados en la Constitución Política, podría pensarse que en lugar de presentarse una "constitucionalización del derecho privado", lo que sucede es que la Constitución se ha visto enriquecida por la normatividad del derecho privado.

En materia de cláusulas abusivas, por ejemplo, la labor de la Sala Civil de la Corte Suprema de Justicia ha sido muy importante al aplicar herramientas del derecho privado. Ahora bien, en algunos casos la protección constitucional se hace necesaria dado que el sistema judicial en Colombia resulta excesivamente lento y por eso,

34 Corte Suprema de Justicia de Colombia, Sala de Casación Civil, XLVI Gaceta Judicial, 60, 21 de febrero de 1938. Corte Suprema de Justicia de Colombia, Sala de Negocios Generales, XLII Gaceta Judicial, 601, 6 de septiembre de 1935. 
mediante la acción de tutela, los consumidores financieros buscan una solución más efectiva a sus conflictos.

De esta manera, si bien hay herramientas del derecho privado y del derecho del consumo para resolver un caso determinado, para utilizar la acción de tutela es necesario acudir a la violación de un derecho fundamental, como el derecho a la vivienda digna ${ }^{35}$ en los créditos hipotecarios.

En este sentido, resulta ilustrativo lo manifestado por la Corte Constitucional en un caso en el que una persona, dada una incapacidad sobreviniente, entró en mora de un crédito hipotecario y la compañía de seguros se rehusó a pagar el crédito argumentando que el deudor al momento de presentarse la invalidez había superado la edad máxima para la cobertura del seguro ${ }^{36}$. La Corte exhortó a las compañías aseguradoras y crediticias a revisar sus contratos para evitar que el estado de ancianidad de las personas quedase desprotegido solamente por el transcurso del tiempo. En esta decisión, la Corte estimó que en el caso se configuraba una violación de los derechos constitucionales a la vida digna, la vivienda y el mínimo vital del deudor del crédito. La Sala resolvió que procedía la acción de tutela contra particulares en relaciones contractuales pues, aunque había en el caso otros medios de defensa judicial, esta acción procede si estos no resultan eficaces para proteger el derecho del accionante o se deba precaver un perjuicio irremediable. De esta manera, señala la Corte, el rol más activo del juez constitucional y la ampliación de la procedencia de la tutela permiten "irradiar la otrora inescrutable esfera de los negocios contractuales". Adicionalmente, la Corte Constitucional ha considerado que tanto el sector bancario como el asegurador realizan actividades de interés

35 El derecho a la vivienda digna ha sido definido por la Corte Constitucional como el orientado a suplir la necesidad de las personas de disponer de un sitio privado, "sea propio o ajeno, que reviste las características para poder realizar de manera digna el proyecto de vida". Entre otras sentencias, Corte Constitucional de Colombia, Sentencia T-079-08, 31 de enero de 2008, magistrado ponente Rodrigo Escobar-Gil. Disponible en: http://www.corteconstitucional. gov.co/relatoria/2008/T-079-08.htm. Corte Constitucional de Colombia, Sentencia T-585-08, 12 de junio de 2008, magistrado ponente Humberto Antonio Sierra-Porto. Disponible en: http://www.corteconstitucional.gov.co/relatoria/2008/t-585-08.htm. Corte Constitucional de Colombia, Sentencia T-331-11, 4 de mayo de 2011, magistrado ponente Nilson Pinilla-Pinilla. Disponible en: http://www.corteconstitucional.gov.co/relatoria/2011/t-331-11.htm

36 Corte Constitucional de Colombia, Sentencia T-136-13, 13 de marzo de 2013, magistrado ponente Jorge Iván Palacio-Palacio. Disponible en: http://www.corteconstitucional.gov.co/ relatoria/2013/t-136-13.htm 
público y los ciudadanos están generalmente en una posición de indefensión frente a estas entidades ${ }^{37}$ y que dado el alcance de los efectos horizontales de la Constitución, los contratos no solamente deben ceñirse a la ley, sino con mayor razón a los mandatos constitucionales ${ }^{38}$.

Las cláusulas aceleratorias, es decir, aquellas cláusulas que permiten al acreedor declarar vencido de forma anticipada el plazo de una obligación cuyo pago se realiza por instalamentos, han sido sujeto de análisis por la jurisprudencia constitucional. En efecto, el artículo 69 de la Ley 45 de 1990 fue declarado exequible por la Corte Constitucional, lo cual permite la posibilidad de estipular la inclusión de cláusulas aceleratorias en las obligaciones sujetas a pago por cuotas periódicas ${ }^{39}$. En esta sentencia, la Corte consideró que "la permisión legal, de carácter general, para pactar cláusulas aceleratorias no es en sí misma contraria al deber de no abuso de los derechos porque ella se funda en el principio de la autonomía de la voluntad y está limitada por precisas condiciones jurídicas". Sin embargo, en esta misma decisión, la Corte indicó que podría presentarse el caso en el que en un contrato de adhesión se pactara una cláusula aceleratoria excesiva por desconocer los límites legales o ser demasiado onerosa para las partes, pero que en esos casos no es competencia de la Corte decidir al respecto.

La Corte Constitucional ha protegido al deudor de créditos hipotecarios en otras circunstancias. Por ejemplo, en la sentencia C-252-9840, la Corte declaró la exequibilidad condicionada del artículo 2229 del Código Civil ${ }^{41}$, según el cual se permite el pago anticipado en el mutuo por parte del deudor "salvo que se hayan pactado intereses". En este caso, se estimó que en los créditos

37 Corte Constitucional de Colombia, Sentencia T-813-12, 16 de octubre de 2012, magistrado ponente Nilson Pinilla-Pinilla. Disponible en: http://www.corteconstitucional.gov.co/ relatoria/2012/t-813-12.htm

38 Corte Constitucional de Colombia, Sentencia T-813-12, 16 de octubre de 2012, magistrado ponente Nilson Pinilla-Pinilla. Disponible en: http://www.corteconstitucional.gov.co/ relatoria/2012/t-813-12.htm

39 Corte Constitucional de Colombia, Sentencia C-332-01, 29 de marzo de 2001, magistrado ponente Manuel José Cepeda-Espinosa. Disponible en: http://www.corteconstitucional.gov. co/relatoria/2001/c-332-01.htm

40 Corte Constitucional de Colombia, Sentencia C-252-98, 21 de mayo de 1998, magistrada ponente Carmenza Isaza de Gómez. Disponible en: http://www.corteconstitucional.gov.co/ relatoria/1998/C-252-98.htm

41 Ley 57 de 1887, Código Civil. Disponible en: http://www.secretariasenado.gov.co/senado/ basedoc/codigo_civil.html 
de vivienda a largo plazo no se aplica el artículo mencionado de manera que el deudor puede pagar anticipadamente su crédito sin lugar a penalidad alguna, dada la protección constitucional que se le brinda al derecho a la vivienda.

\section{Protección legal}

El artículo 830 del Código de Comercio ${ }^{42}$ colombiano indica que "el que abuse de sus derechos estará obligado a indemnizar los perjuicios que cause".

La Corte Suprema de Justicia aceptó la aplicación del no abuso del derecho en materia contractual en $1994^{43}$, en una decisión en la que la Corte consideró "comprobada la ocurrencia de varias actuaciones abusivas desplegadas por una entidad de crédito al concluir, ejecutar y liquidar una operación de préstamo hipotecario". Esta misma Corporación en 2001 manifestó que se consideraban abusivas aquellas cláusulas que ${ }^{44}$.

a. "que su negociación no haya sido individual,

b. que lesionen los requerimientos emergentes de la buena fe negocial,

c. que generen un desequilibrio significativo de cara a los derechos y las obligaciones que contraen las partes".

Uno de los principales retos que debe afrontar el derecho en materia de contratos de adhesión es la posibilidad de que se introduzcan en su contenido cláusulas abusivas. Por esta razón, en

42 Decreto 410 de 1971, por el cual se expide el Código de Comercio, 33.339 Diario Oficial, 16 de junio de 1971. Disponible en: http://www.secretariasenado.gov.co/senado/basedoc/codigo_comercio.html

43 Corte Suprema de Justicia de Colombia, Sala de Casación Civil, Sentencia 125, 19 de octubre de 1994, magistrado ponente Carlos Esteban Jaramillo-Schloss. Disponible en: http://www. urosario.edu.co/Laudos-Arbitrales/Documentos/Sentencia_Fiducia_Corte_Suprema_1994/. Acerca de la figura del abuso del derecho en materia contractual, ver, entre otros: JoRGE Santos-Ballesteros, Abuso contractual, en Realidades y tendencias del derecho en el siglo XXI, Tomo IV, Derecho privado, Vol. 1, 287-308 (Temis, Pontificia Universidad Javeriana, Bogotá, 2010). Sergio Muñoz-Laverde, El principio de buena fe y su incidencia en la interpretación del contrato. Nulidad de las cláusulas abusivas en el derecho colombiano, en Realidades y tendencias del derecho en el siglo XXI, Tomo IV. Derecho privado, Vol. 1, 211-246 (Temis, Pontificia Universidad Javeriana, Bogotá, 2010). JuAn Pablo CÁrdenas, Justicia y abuso contractual. Los contratos en el derecho privado, 693 ss. (Editorial Legis, Bogotá, 2007).

44 Corte Suprema de Justicia de Colombia, Sala de Casación Civil, Expediente 5670, 2 de febrero de 2001, magistrado ponente Carlos Ignacio Jaramillo-Jaramillo. 
materia de servicios públicos domiciliarios, la Ley 142 de $1994^{45}$ estableció en su artículo 133 una lista de 26 cláusulas en las que se presume que hay abuso de la posición dominante de la empresa de servicios públicos en los contratos. Posteriormente, la Ley 1328 de 2009 protege al consumidor financiero contra este tipo de cláusulas, como se analizará más adelante.

Sin embargo, solamente a partir de la Ley 1480 de 2011 se establece una protección general a los consumidores contra las cláusulas abusivas ${ }^{46}$. La Ley define lo que se considera una cláusula abusiva y señala una lista de cláusulas que se consideran abusivas y de incluirse en un contrato serán ineficaces de pleno derecho ${ }^{47}$. Este Estatuto indica adicionalmente en su artículo 44: "La nulidad o ineficacia de una cláusula no afectará la totalidad del contrato, en la medida en que este pueda subsistir sin las cláusulas nulas o ineficaces". Esta norma se presta para confusión pues el artículo 42 se refería a la ineficacia de pleno derecho de las cláusulas abusivas y luego el artículo 44 menciona como sanción a estas cláusulas no solo la ineficacia de pleno derecho sino también la nulidad, pero sin explicar en qué casos opera cada una.

Ya que el legislador no lo explica, podría interpretarse que mientras la nulidad se aplica respecto de cláusulas abusivas que correspondan a la definición general dada por la ley, en los casos de incorporación de una cláusula que esté en la lista del artículo 43 la sanción será la ineficacia de pleno derecho. Sin embargo, tanto el artículo 42, que define las cláusulas abusivas, como el artículo 43, que presenta la lista no taxativa de tales cláusulas, se refieren a la ineficacia de pleno derecho, lo que deja abierta la discusión.

45 Ley 142 de 1994, por la cual se establece el régimen de los servicios públicos domiciliarios y se dictan otras disposiciones, 41.433 Diario Oficial, 11 de julio de 1994. Disponible en: http:// www.secretariasenado.gov.co/senado/basedoc/ley_0142_1994.html

46 "Artículo 42. Son cláusulas abusivas aquellas que producen un desequilibrio injustificado en perjuicio del consumidor y las que, en las mismas condiciones, afecten el tiempo, modo o lugar en que el consumidor puede ejercer sus derechos. Para establecer la naturaleza y magnitud del desequilibrio, serán relevantes todas las condiciones particulares de la transacción particular que se analiza. Los productores y proveedores no podrán incluir cláusulas abusivas en los contratos celebrados con los consumidores. En caso de ser incluidas serán ineficaces de pleno derecho". Ley 1480 de 2011, por medio de la cual se expide el Estatuto del Consumidor y se dictan otras disposiciones, 48.220 Diario Oficial, 12 de octubre de 2011. Disponible en: http:// www.secretariasenado.gov.co/senado/basedoc/ley_1480_2011.html

47 Ley 1480 de 2011, por medio de la cual se expide el Estatuto del Consumidor y se dictan otras disposiciones, artículo 43, 48.220 Diario Oficial, 12 de octubre de 2011. Disponible en: http:// www.secretariasenado.gov.co/senado/basedoc/ley_1480_2011.html 


\section{Protección especial}

\section{Protección al consumidor financiero}

El interés por la protección del consumidor financiero ha sido cada vez mayor en el mundo, en particular a partir de la crisis financiera de Estados Unidos en 2008 generada, entre otros factores, por la falta de información y control de los créditos hipotecarios que ocasionaron su crecimiento irresponsable ${ }^{48}$.

En Colombia, por medio de la Ley 1328 de 2009 se creó el Estatuto del Consumidor Financiero que estableció los principios y reglas que protegen a los consumidores financieros en sus relaciones con las entidades vigiladas por la Superintendencia Financiera de Colombia, como las compañías de seguros y las entidades bancarias.

Esta ley establece en su artículo 7 literal e) que las entidades vigiladas tendrán como obligación especial: "Abstenerse de incurrir en conductas que conlleven abusos contractuales o de convenir cláusulas que puedan afectar el equilibrio del contrato o dar lugar a un abuso de posición dominante contractual". En el artículo 11, además, se señala una lista de cinco estipulaciones contractuales que están prohibidas por considerarse abusivas y que se tendrán por no escritas en caso de incorporación en los contratos.

La Superintendencia Financiera en la Circular Externa 039 de $2011^{49}$ presentó ejemplos concretos de lo que consideraba implicaban cláusulas y prácticas abusivas, a partir de lo establecido en el Estatuto del Consumidor.

El Banco Mundial publicó unas recomendaciones para proteger a los consumidores financieros en las que analiza las buenas prácticas que deben seguir las instituciones para que haya confianza mutua entre los bancos y los consumidores ${ }^{50}$. Reglas claras, trans-

48 Superintendencia Financiera de Colombia, Los mecanismos de protección al consumidor financiero. Apuntes del Supervisor No. 5 (2013). Disponible en: https://www.superfinanciera. gov.co/SFCant/ApuntesSupervisor/20130911apuntes05.pdf

49 Superintendencia Financiera de Colombia, Circular Externa 039 de 2011, 6 de septiembre de 2011. Disponible en: https://www.superfinanciera.gov.co/jsp/loader.jsf?1Servicio=Publicacion es\&lTipo=publicaciones\&lFuncion $=$ loadContenidoPublicacion\&id $=10082067$, https://www. coopcentral.com.co/documentos/ConsumidorFinanciero/6Normatividad/CircularExterna039de2011.pdf

50 Banco Mundial, Buenas prácticas para la protección al consumidor financiero (Banco Internacional de Reconstrucción y Fomento, Banco Mundial, Washington, junio de 2012). Disponible en: http://siteresources.worldbank.org/EXTFINANCIALSECTOR/ 
parencia, información, mecanismos adecuados para la resolución de conflictos y prohibición de prácticas abusivas son algunos de los pilares del documento.

En Colombia no hay una entidad que se dedique específicamente a la protección de los consumidores financieros como sucede en otros países ${ }^{51}$. La Ley 1328 de 2009 reguló la Defensoría del Consumidor Financiero de manera que las entidades vigiladas que defina el Gobierno Nacional deberán contar con un Defensor del Consumidor que atienda a los clientes de estas entidades de manera oportuna y gratuita.

La Ley 1328 de 2009, adicionalmente le otorgó competencias a la Superintendencia financiera para calificar e identificar prácticas y cláusulas abusivas en el artículo 11 literal e). Esta disposición fue demandada por inconstitucionalidad pues los accionantes alegaron que por vulneración de los artículos 113, 150, 151, 152 y 333 de la carta política "[e]l Congreso de la República no podía delegar en la Superintendencia Financiera la posibilidad de definir cuáles son las cláusulas y prácticas abusivas". La Corte Constitucional declaró exequible el artículo en cuestión, pues consideró que en virtud de las potestades de inspección, vigilancia y control que tiene el Ejecutivo, éste puede intervenir en la regulación de la economía en la medida en que se sujete a los parámetros previamente definidos por la ley, intervención que se encuentra justificada por la complejidad técnica de los asuntos económicos y la necesidad de regulación oportuna ${ }^{52}$.

\section{Aplicación de la norma especial}

Dado que hay una protección general a los consumidores por medio de la Ley 1480 de 2011 y una protección especial al consumidor

Resources/282884-1339624653091/8703882-1339624678024/8703850-1340026711043/8710076 1340026729001/FinConsumerProtection_GoodPractices_SPANISH_FINAL.pdf

51 Por ejemplo, en México, la Comisión Nacional para la Defensa de los Usuarios de los Servicios Financieros (CONDUSEF) o en Estados Unidos, el Consumer Financial Protection Bureau (CFPB).

52 Corte Constitucional de Colombia, Sentencia C-909-12, 7 de noviembre de 2012, magistrado ponente Nilson Pinilla-Pinilla. Disponible en: http://www.corteconstitucional.gov.co/ relatoria/2012/c-909-12.htm. En sentido similar se ha manifestado la Corte en las sentencias C-352 de 2009 y C-228 de 2010. Corte Constitucional de Colombia, Sentencia C-352-09, 20 de mayo de 2009, magistrado ponente Luis Ernesto Vargas-Silva. Disponible en: http://www. corteconstitucional.gov.co/relatoria/2009/C-352-09.htm. Corte Constitucional de Colombia, Sentencia C-228-10, 24 de marzo de 2010, magistrado ponente Luis Ernesto Vargas-Silva. Disponible en: http://www.corteconstitucional.gov.co/relatoria/2010/c-228-10.htm 
financiero en la Ley 1328 de 2009, es importante tener claridad sobre la legislación aplicable a los consumidores de créditos hipotecarios, tema que analiza el presente texto. Hay diversos criterios para determinar la normatividad que debe prevalecer en caso de coexistencia de normas en materia de derecho de consumo ${ }^{53}$.

En Argentina, por ejemplo, la Ley de defensa del consumidor (Ley 24.240) ${ }^{54}$ establece en su artículo tercero que sus disposiciones "se integran con las normas generales y especiales aplicables a las relaciones de consumo (...). En caso de duda sobre la interpretación de los principios que establece esta ley prevalecerá la más favorable al consumidor" (itálicas fuera de texto). En España, en cambio, la norma general de defensa de los consumidores (Real Decreto Legislativo 1/2007) excluye expresamente normativas sectoriales.

La doctrina ha sugerido también que la unificación de normas que abarque todas las relaciones de consumo, aunque conlleva una gran dificultad, es ideal para la seguridad de los consumidores ${ }^{55}$.

En el caso colombiano, aunque la Ley 1480 de 2011 es posterior, es de carácter general; por ello, dado que la Ley 1328 de 2009 es especial, tiene aplicación preferente por el principio hermenéutico según el cual la norma especial prima sobre la norma general.

El Estatuto colombiano ha debido incluir, en nuestra opinión, una norma sobre aplicación de la legislación más favorable al consumidor. En lugar de ello, el artículo segundo de la Ley 1480 establece que:

(...) Las normas contenidas en esta ley son aplicables en general a las relaciones de consumo y a la responsabilidad de los productores y proveedores frente al consumidor en todos los sectores de la economía respecto de los cuales no

53 María Elisa Camacho-López, Modelos legislativos en materia de consumo en el Derecho comparado, en Perspectivas del Derecho del Consumo, Memorias del seminario La protección al consumidor en el Derecho Colombiano, 33-76, 49 ss. (Carmen Ligia Valderrama-Rojas, dir., Editorial Universidad Externado de Colombia, Bogotá, 2013).

54 Argentina, Ley 24.240, Ley de defensa del consumidor, normas de protección y defensa de los consumidores, autoridad de aplicación, procedimiento y sanciones, disposiciones finales. Sancionada: 22 de septiembre de 1993. Promulgada parcialmente: 13 de octubre de 1993. Disponible en: http://infoleg.mecon.gov.ar/infolegInternet/anexos/0-4999/638/texact.htm

55 María Elisa Camacho-López, Modelos legislativos en materia de consumo en el Derecho comparado, en Perspectivas del Derecho del Consumo, Memorias del seminario La protección al consumidor en el Derecho Colombiano, 33-76, 55 (CARmen Ligia Valderrama-Rojas, dir., Editorial Universidad Externado de Colombia, Bogotá, 2013). 
exista regulación especial, evento en el cual aplicará la regulación especial y suplementariamente las normas establecidas en esta Ley.

Acerca de la coexistencia de normas en materia de consumidores financieros, la Superfinanciera ${ }^{56}$ ha explicado que la Ley $1480 \mathrm{de}$ 2011 se aplicará revisando en cada caso si la situación está regulada de manera integral en la Ley 1328 de 2009, caso en el cual se aplicará esta normatividad, solo en caso contrario se aplicará la norma general. Acerca de las cláusulas abusivas en particular, esta entidad ha manifestado que "se aplican de manera preferente los artículos 11 y 12 de la Ley 1328 de 2009 y el numeral 10 del Capítulo Sexto del Título Primero de la Circular Básica Jurídica, CBJ, relacionados con cláusulas y prácticas abusivas, frente a lo dispuesto en los artículos 42 y 43 de la Ley 1480 de 2011”.

Comparando el manejo de las cláusulas abusivas en los créditos hipotecarios en España, revisado al comienzo de este texto, en Colombia al iniciar los procesos ejecutivos el título ejecutivo que se aduce, por lo general, es el pagaré que ha firmado el adquirente del crédito. De esta manera, en el proceso ejecutivo no se presenta el contrato fuente del crédito y por ello resultaría complejo, aunque no imposible, alegar la cláusula abusiva del contrato que tiene una relación causal con el pagaré objeto del litigio.

Adicionalmente, se ha mencionado la ambigüedad que hay respecto de la sanción a las cláusulas abusivas en el ordenamiento jurídico colombiano. En el Estatuto del Consumidor Financiero se considera que este tipo de cláusulas se reputan como no escritas, mientras que la Ley 1480 de 2011 hace alusión, como se explicó anteriormente, tanto a la nulidad como a la ineficacia de pleno derecho. Estas circunstancias no son claras para la efectividad de la protección al consumidor financiero en materia de cláusulas abusivas en un proceso ejecutivo. Podría considerarse que al ser cláusulas ineficaces de pleno derecho, no requieren declaración del juez al respecto o si se considera que se requiere una declaración de nulidad por parte del juez podría iniciarse un proceso ordinario al cual quedaría sujeta la decisión del proceso ejecutivo en virtud del

56 Superintendencia Financiera de Colombia, Concepto 2013008465-008, No. 46 (8 de julio de 2013). Disponible en: https://www.superfinanciera.gov.co/SFCant/Normativa/PrincipalesPublicaciones/boletinej/boletin4613/Proteccion\%20Consumidor.html 


\section{artículo 170 del Código de Procedimiento Civil ${ }^{57}$ o el artículo 161} del Código General del Proceso ${ }^{58}$.

57 Decreto 1400 de 1970, Código de Procedimiento Civil, 33.150 Diario Oficial, 21 de septiembre de 1970 (Código derogado por la Ley 1564 de 2012 en los términos establecidos en el artículo 626). Disponible en: http://www.secretariasenado.gov.co/senado/basedoc/codigo_procedimiento_civil.html

58 Ley 1564 de 2012, por medio de la cual se expide el Código General del Proceso y se dictan otras disposiciones, 48.489 Diario Oficial, 12 de julio de 2012. Disponible en: http://www. secretariasenado.gov.co/senado/basedoc/ley_1564_2012.html 


\section{CONCLUSIONES}

Las crisis financieras acaecidas durante los últimos años afectan, entre otros, los créditos hipotecarios, lo que impide a las personas acceder a una vivienda propia o hace que pierdan la que tenían.

De este modo, en España y Colombia las crisis financieras se han caracterizado por presentar un incremento exorbitante en los precios de los inmuebles y por la imposibilidad de pago de los deudores hipotecarios, por lo que las entidades de crédito reaccionaron frente a los incumplimientos mediante la acción de ejecución hipotecaria, en las que no se permitía discutir la abusividad de las cláusulas contractuales. Se presentaron entonces, innumerables desahucios y las personas perdieron su vivienda.

Para enfrentar estos fenómenos, los jueces han intervenido en el derecho privado para evitar que un difícil contexto económico generalizado afecte de forma excesiva a los deudores hipotecarios. En ese sentido, en contextos como el español, han sido proclives a analizar el título de cobro - las cláusulas del contrato de crédito hipotecario - en el marco de los procesos ejecutivos. Adicionalmente, la regulación de las cláusulas abusivas se ha desarrollado, principalmente en el derecho del consumo, para evitar los desequilibrios que se presentan entre partes que se encuentran en desigualdad de condiciones, pues una de ellas, dada su posición económica, impone a otra sus condiciones.

Así, se destacan importantes pronunciamientos jurisprudenciales en el ámbito tanto europeo como español que, frente al examen de los contratos de crédito hipotecario, llevaron a los juzgadores a permitir que el deudor pudiera solicitar la declaratoria de abusiva de las cláusulas en el marco de los procesos ejecutivos y, con ello, la expedición de nuevas leyes modificatorias del régimen procesal que lo legitimaran expresamente.

En Colombia, de forma similar, fueron los jueces quienes impulsaron una modificación legislativa. En efecto, la Corte Constitucional declaró inexequibles todos los artículos del Estatuto Orgánico del Sistema Financiero que desarrollaban el sistema UPAC, lo que llevó a la expedición de la Ley 546 de 1999 que reemplazó el UPAC por la UVR para atar los créditos exclusivamente al IPC y así evitar que los deudores se enfrentaran a unas tasas muy diferentes a las 
esperadas. Por otra parte, en cuanto a las cláusulas abusivas, hay coexistencia entre la ley especial para el consumidor financiero y el Estatuto del Consumidor en Colombia. La regulación de estas cláusulas genera inquietudes acerca de la sanción que se les debe aplicar dada la ambigüedad de la redacción de las normas, por lo que serán los jueces los llamados a interpretar estas reglas de la forma más protectora a los consumidores. 


\section{BIBLIOGRAFíA}

\section{Libros}

Arango, Miguel, Evolución y crisis del sistema financiero colombiano (Serie Estudios y Perspectivas, 11, Ed. Cepal-Naciones Unidas, Bogotá, junio de 2006). Disponible en: http://repositorio.cepal.org/bitstream/handle/11362/4809/ S0600444_es.pdf?sequence $=1$

CÁrdenas, JuAn Pablo, Justicia y abuso contractual. Los contratos en el derecho privado (Editorial Legis, Bogotá, 2007).

Díez-Picazo, luis; Clavero-Arévalo, Manuel \& Abascal-Zamora, José María, Las condiciones generales de la contratación y cláusulas abusivas (Ediciones Civitas, Madrid, 1996).

Llamas-Pombo, Eugenio, Orientaciones sobre el concepto y el método del derecho civil (Editorial Pontificia Universidad Javeriana, Bogotá, 2009).

Pasquau-Liaño, Miguel, Código Civil y ordenamiento jurídico. Otra reflexión sobre el devenir del Derecho Civil (Editorial Comares, Granada, 1994).

\section{Contribución en obras colectivas}

Camacho-López, María Elisa, Modelos legislativos en materia de consumo en el Derecho comparado, en Perspectivas del Derecho del Consumo, Memorias del seminario La protección al consumidor en el Derecho Colombiano, 33-76 (CARMEN Ligia VALDERrama-Rojas, dir., Editorial Universidad Externado de Colombia, Bogotá, 2013).

Muñoz-Laverde, Sergio, El principio de buena fe y su incidencia en la interpretación del contrato. Nulidad de las cláusulas abusivas en el derecho colombiano, en Realidades $y$ tendencias del derecho en el siglo XXI, Tomo IV. Derecho privado, Vol. 1, 211246 (Temis, Pontificia Universidad Javeriana, Bogotá, 2010).

Santos-Ballesteros, Jorge, Abuso contractual, en Realidades y tendencias del derecho en el siglo XXI, Tomo IV, Derecho privado, Vol. 1, 287-308 (Temis, Pontificia Universidad Javeriana, Bogotá, 2010).

\section{Revistas}

Blanco-García, Ana Isabel, Control de oficio de las cláusulas abusivas en la ejecución hipotecaria, 7 Revista CESCO de Derecho de Consumo, 195-217 (2013). Disponible en: https://cesco.revista.uclm.es/index.php/cesco/article/view/337/312

Cámara-Lapuente, Sergio, ¿De verdad puede controlarse el precio de los contratos mediante la normativa de cláusulas abusivas? De la STJUE de 3 junio 2010 (Caja de Madrid, C-484/08) y su impacto aparente y real en la jurisprudencia española a la STS (pleno) de 9 mayo 2013 sobre las cláusulas suelo, 5 Cuadernos de Derecho Transnacional, 2, 209-233 (2013). Disponible en: http://e-revistas.uc3m.es/index. 
php/CDT/article/view/1815

Fernández-Seijo, José María, Un año después de la Sentencia del caso Aziz, 286 Revista Món Jurídic, Revista del Ilustre Colegio de Abogados de Barcelona, 16-17 (2014). Disponible en: http://dialnet.unirioja.es/servlet/articulo?codigo $=4680285$

Gómez-González, José Eduardo; Silva, Luisa; Restrepo, Sergio \& Salazar, Mauricio, Flujos de capital y fragilidad financiera en Colombia, 30 Ensayos sobre Politica Económica, 69, 67-109 (2012). Disponible en: http://www.scielo.org.co/scielo. php?script $=$ sci_arttext\&pid $=$ S0120-44832012000300003\&lng $=$ en $\& n r m=i s o \&$ tlng=es

Henao-Pérez, Juan Carlos, El juez constitucional: un actor de las políticas públicas, 15 Revista de Economía Institucional, 29, 67-102 (2013). Disponible en: http://www. economiainstitucional.com/esp/vinculos/pdf/No29/jhenao29.pdf

Quinche-Ramírez, Manuel Fernando \& Rivera-Rugeles, Juan Camilo, El control judicial de las políticas públicas como instrumento de inclusión de los derechos humanos, 121 Revista Vniversitas, 113-137 (2010). Disponible en: http://www. redalyc.org/pdf/825/82518988005.pdf

Rodríguez-SÁnchez-Tabernero, Soledad, Sentencia del Tribunal de Justicia de la Unión Europea, de 14 de marzo de 2013, asunto C-415/11, Mohamed Aziz c. Catalunyacaixa. Adecuación al Derecho de la UE del procedimiento de ejecución hipotecaria español, 1 Reseñas de Jurisprudencia Civil, Ars Iuris Salmanticensis, Universidad de Salamanca, 227-293 (enero-junio, 2013). Disponible en: revistas. usal.es/index.php/ais/article/download/11545/11964

Villar-Gómez, Leonardo, Salamanca-Rojas, David M. \& Murcia-Pabón, Andrés, Crédito, represión financiera y flujos de capitales en Colombia: 1974-2003, 55 Desarrollo y Sociedad, Universidad de los Andes, 167-209 (2005). Disponible en: http://www.researchgate.net/publication/4747000_Crdito_represin_ financiera_y_flujos_de_capitales_en_Colombia_1974-2003

\section{Working papers}

Clavijo, Sergio; Vera, Alejandro; Salcedo, María P.; Carvajal, Jennifer; Galindo, Arturo \& Castellani, Francesca, El crédito hipotecario en Colombia: Evaluación del impacto regulatorio pos-crisis (Working paper, investigación realizada por ANIF (Asociación Nacional de Instituciones Financieras) para el BID (Banco Interamericano de Desarrollo), mayo de 2011). Disponible en: http://anif.co/sites/ default/files/uploads/Anif-BID0511.pdf

Roulllon, Adolfo, Colombia: Derechos de Crédito y Procesos Concursales (Working Paper 70442, Banco Mundial, Grupo de Finanzas, Sector Privado e Infraestructura, Región de América Latina y el Caribe, 2006). Disponible en: http://documents.worldbank.org/curated/en/2006/05/16500605/colombiaderechos-de-crédito-y-procesos-concursales 


\section{Tratados internacionales}

Tratado constitutivo de la Comunidad Económica Europea, Tratado CEE, Roma, 25 de marzo de 1957. Disponible en: http://eur-lex.europa.eu/legal-content/ES/ TXT/?uri=URISERV:xy0023

Unión Europea, Tratado de Funcionamiento de la Unión Europea, TFUE, Roma, 25 de marzo de 1957. Versión consolidada disponible en: http://www.boe.es/buscar/ doc.php?id=DOUE-Z-2010-70006

\section{Normatividad internacional}

Argentina, Ley 24.240, Ley de defensa del consumidor, normas de protección y defensa de los consumidores, autoridad de aplicación, procedimiento y sanciones, disposiciones finales. Sancionada: 22 de septiembre de 1993. Promulgada parcialmente: 13 de octubre de 1993. Disponible en: http://infoleg.mecon.gov. ar/infolegInternet/anexos/0-4999/638/texact.htm

Consejo de las Comunidades Europeas, Directiva 93/13/CEE del Consejo, de 5 de abril de 1993, sobre las cláusulas abusivas en los contratos celebrados con consumidores. Disponible en: http://eur-lex.europa.eu/LexUriServ/LexUriServ. do?uri=CELEX:31993L0013:ES:HTML

España, Ley 7/1998, de 13 de abril, sobre condiciones generales de la contratación, 89 Boletín Oficial del Estado, BOE, 14 de abril de 1998. Disponible en: http://www. boe.es/buscar/act.php?id=BOE-A-1998-8789

España, Ley 1/2000, de 7 de enero, Ley de Enjuiciamiento Civil, 7 Boletín Oficial del Estado, BOE, 8 de enero de 2000. Disponible en: http://www.boe.es/boe/ dias/2000/01/08/pdfs/A00575-00728.pdf

España, Ley 1/2013, de 14 de mayo, de medidas para reforzar la protección a los deudores hipotecarios, reestructuración de deuda y alquiler social, 116 Boletín Oficial del Estado, BOE, 15 de mayo de 2013. Disponible en: http://www.boe.es/boe/ dias/2013/05/15/pdfs/BOE-A-2013-5073.pdf

España, Real Decreto Legislativo 1/2007, de 16 de noviembre, por el que se aprueba el texto refundido de la Ley General para la Defensa de los Consumidores y Usuarios y otras leyes complementarias, 287 Boletín Oficial del Estado, BOE, 30 de noviembre de 2007. Disponible en: http://www.boe.es/buscar/act. php?id=BOE-A-2007-20555

España, Real Decreto Ley 8 de 2011, de 1 de julio, de medidas de apoyo a los deudores hipotecarios, de control del gasto público y cancelación de deudas con empresas y autónomos contraídas por las entidades locales, de fomento de la actividad empresarial e impulso de la rehabilitación y de simplificación administrativa, 161 Boletín Oficial del Estado, BOE, 7 de julio de 2011. Disponible en: http:// www.boe.es/boe/dias/2011/07/07/pdfs/BOE-A-2011-11641.pdf

España, Real Decreto Ley 6 de 2012, de 9 de marzo, de medidas urgentes de protección de deudores hipotecarios sin recursos, 60 Boletín Oficial del Estado, BOE, 10 de marzo de 2012. Disponible en: http://www.boe.es/diario_boe/txt. php?id=BOE-A-2012-3394 
España, Real Decreto Ley 27 de 2012, de 15 de noviembre, de medidas urgentes para reforzar la protección a los deudores hipotecarios, 276 Boletín Oficial del Estado, BOE, 16 de noviembre de 2012. Disponible en: http://www.boe.es/diario_boe/ txt.php?id=BOE-A-2012-14115

\section{Normatividad colombiana}

Decreto 1400 de 1970, Código de Procedimiento Civil, 33.150 Diario Oficial, 21 de septiembre de 1970 (Código derogado por la Ley 1564 de 2012 en los términos establecidos en el artículo 626). Disponible en: http://www.secretariasenado.gov. co/senado/basedoc/codigo_procedimiento_civil.html

Ley 1564 de 2012, por medio de la cual se expide el Código General del Proceso y se dictan otras disposiciones, 48.489 Diario Oficial, 12 de julio de 2012. Disponible en: http://www.secretariasenado.gov.co/senado/basedoc/ley_1564_2012.html

Decreto 410 de 1971, por el cual se expide el Código de Comercio, 33.339 Diario Oficial, 16 de junio de 1971. Disponible en: http://www.secretariasenado.gov.co/senado/ basedoc/codigo_comercio.html

Decreto 2330 de 1998, por el cual se declara el Estado de Emergencia Económica y Social, 43.430 Diario Oficial, 16 de noviembre de 1998. Disponible en: http://www. secretariasenado.gov.co/senado/basedoc/decreto_2330_1998.html

Decreto 2331 de 1998, por el cual se dictan medidas tendientes a resolver la situación de los sectores financiero y cooperativo, aliviar la situación de los deudores por créditos de vivienda y de los ahorradores de las entidades cooperativas en liquidación, mediante la creación de mecanismos institucionales y de financiación y la adopción de disposiciones complementaria, 43.430 Diario Oficial, 16 de noviembre de 1998. Disponible en: http://www.secretariasenado. gov.co/senado/basedoc/decreto_2331_1998.htm

Ley 57 de 1887, Código Civil. Disponible en: http://www.secretariasenado.gov.co/senado/ basedoc/codigo_civil.html

Ley 45 de 1990, por la cual se expiden normas en materia de intermediación financiera, se regula la actividad aseguradora, se conceden unas facultades y se dictan otras disposiciones, 39.607 Diario Oficial, 19 de diciembre de 1990. Disponible en: http:// www.cancilleria.gov.co/sites/default/files/Normograma/docs/ley_0045_1990.htm

Ley 09 de 1991, por la cual se dictan normas generales a las que deberá sujetarse el Gobierno Nacional para regular los cambios internacionales y se adoptan medidas complementarias, 39.634 Diario Oficial, 17 de enero de 1991. Disponible en: http://www.banrep.gov.co/sites/default/files/paginas/ LEY09DE1991CONHIPERVINCULOS-1.pdf

Ley 35 de 1993, por la cual se dictan normas generales y se señalan en ellas los objetivos y criterios a los cuales debe sujetarse el Gobierno Nacional para regular las actividades financiera, bursátil y aseguradora y cualquier otra relacionada con el manejo, aprovechamiento e inversión de recursos captados del público y se dictan otras disposiciones en materia financiera y aseguradora, 40.710 Diario Oficial, 5 de enero de 1993. Disponible en: http://www.secretariasenado.gov.co/ senado/basedoc/ley_0035_1993.html 
Ley 142 de 1994, por la cual se establece el régimen de los servicios públicos domiciliarios y se dictan otras disposiciones, 41.433 Diario Oficial, 11 de julio de 1994. Disponible en: http://www.secretariasenado.gov.co/senado/basedoc/ley_0142_1994.html

Ley 546 de 1999, por la cual se dictan normas en materia de vivienda, se señalan los objetivos y criterios generales a los cuales debe sujetarse el Gobierno Nacional para regular un sistema especializado para su financiación, se crean instrumentos de ahorro destinado a dicha financiación, se dictan medidas relacionadas con los impuestos y otros costos vinculados a la construcción y negociación de vivienda y se expiden otras disposiciones, 43.827 Diario Oficial, 23 de diciembre de 1999. Disponible en: http://www.secretariasenado.gov.co/senado/basedoc/ ley_0546_1999.htm

Ley 1328 de 2009, por la cual se dictan normas en materia financiera, de seguros, del mercado de valores y otras disposiciones, 47.411 Diario Oficial, 15 de julio de 2009. Disponible en: http://www.secretariasenado.gov.co/senado/basedoc/ ley_1328_2009.html

Ley 1480 de 2011, por medio de la cual se expide el Estatuto del Consumidor y se dictan otras disposiciones, 48.220 Diario Oficial, 12 de octubre de 2011. Disponible en: http://www.secretariasenado.gov.co/senado/basedoc/ley_1480_2011.html

Superintendencia Financiera de Colombia, Circular Externa 039 de 2011, 6 de septiembre de 2011. Disponible en: https://www.superfinanciera.gov.co/jsp/loader.jsf?1Servi cio $=$ Publicaciones\&lTipo $=$ publicaciones $\& 1$ Funcion $=$ loadContenidoPublicacio n\&id=10082067, https://www.coopcentral.com.co/documentos/ConsumidorFin anciero/6Normatividad/CircularExterna039de2011.pdf

\section{Jurisprudencia internacional}

Tribunal Constitucional Español, Sala Primera, Sentencia 18 de 1984, 7 de febrero de 1984. Disponible en: http://www.tribunalconstitucional.es/es/jurisprudencia/ Paginas/Sentencia.aspx?cod=16897

Tribunal de Justicia de la Unión Europea, Asunto Mohamed Aziz c. Catalunyacaixa, 14 de marzo de 2013. Disponible en: http://curia.europa.eu/juris/document/ document.jsf?text $=\&$ docid $=135024 \&$ pageIndex $=0 \&$ doclang $=$ es $\&$ mode $=1$ st $\&$ di $\mathrm{r}=\&$ occ $=$ first $\&$ part $=1 \&$ cid $=447203$

Tribunal Supremo de España, Sala Civil, Sentencia 99/2009, de 4 de marzo de 2009, Recurso 535/2004, magistrado ponente Encarnación Roca-Trías. Disponible en: http://supremo.vlex.es/vid/concesion-automoviles-interpretacionadhesion-57206818

Tribunal Supremo de España, Sala Civil, Sentencia 406/2012, de 18 de junio de 2012, Recurso 46/2010, magistrado ponente Francisco Javier OrduñaMoreno. Disponible en: http://portaljuridico.lexnova.es/jurisprudencia/ JURIDICO/147801/sentencia-ts-406-2012-sala-1-de-18-de-junio-prestamohipotecario-usura-intereses

Tribunal Supremo de España, Sala Civil, Sentencia 241, 9 de mayo de 2013, magistrado ponente Rafael Gimeno-Bayon Cobos. Disponible en: http://www.uclm.es/ Actividades/repositorio/pdf/doc_4591_6079.pdf 


\section{Jurisprudencia colombiana}

Corte Constitucional de Colombia, Sentencia C-252-98, 21 de mayo de 1998, magistrada ponente Carmenza Isaza de Gómez. Disponible en: http://www. corteconstitucional.gov.co/relatoria/1998/C-252-98.htm

Corte Constitucional de Colombia, Sentencia C-136-99, 4 de marzo de 1999, magistrado ponente José Gregorio Hernández. Disponible en: http://www. corteconstitucional.gov.co/relatoria/1999/c-136-99.htm

Corte Constitucional de Colombia, Sentencia C-332-01, 29 de marzo de 2001, magistrado ponente Manuel José Cepeda-Espinosa. Disponible en: http://www. corteconstitucional.gov.co/relatoria/2001/c-332-01.htm

Corte Constitucional de Colombia, Sentencia C-352-09, 20 de mayo de 2009, magistrado ponente Luis Ernesto Vargas-Silva. Disponible en: http://www. corteconstitucional.gov.co/relatoria/2009/C-352-09.htm

Corte Constitucional de Colombia, Sentencia C-228-10, 24 de marzo de 2010, magistrado ponente Luis Ernesto Vargas-Silva. Disponible en: http://www. corteconstitucional.gov.co/relatoria/2010/c-228-10.htm

Corte Constitucional de Colombia, Sentencia C-909-12, 7 de noviembre de 2012, magistrado ponente Nilson Pinilla-Pinilla. Disponible en: http://www. corteconstitucional.gov.co/relatoria/2012/c-909-12.htm

Corte Constitucional de Colombia, Sentencia T-079-08, 31 de enero de 2008, magistrado ponente Rodrigo Escobar-Gil. Disponible en: http://www.corteconstitucional. gov.co/relatoria/2008/T-079-08.htm

Corte Constitucional de Colombia, Sentencia T-585-08, 12 de junio de 2008, magistrado ponente Humberto Antonio Sierra-Porto. Disponible en: http://www. corteconstitucional.gov.co/relatoria/2008/t-585-08.htm

Corte Constitucional de Colombia, Sentencia T-331-11, 4 de mayo de 2011, magistrado ponente Nilson Pinilla-Pinilla. Disponible en: http://www.corteconstitucional. gov.co/relatoria/2011/t-331-11.htm

Corte Constitucional de Colombia, Sentencia T-813-12, 16 de octubre de 2012, magistrado ponente Nilson Pinilla-Pinilla. Disponible en: http://www.corteconstitucional. gov.co/relatoria/2012/t-813-12.htm

Corte Constitucional de Colombia, Sentencia T-136-13, 13 de marzo de 2013, magistrado ponente Jorge Iván Palacio-Palacio. Disponible en: http://www. corteconstitucional.gov.co/relatoria/2013/t-136-13.htm

Corte Suprema de Justicia de Colombia, Sala de Casación Civil, XLVI Gaceta Judicial, 60, 21 de febrero de 1938.

Corte Suprema de Justicia de Colombia, Sala de Negocios Generales, XLII Gaceta Judicial, 601, 6 de septiembre de 1935.

Corte Suprema de Justicia de Colombia, Sala de Casación Civil, Sentencia 125, 19 de octubre de 1994, magistrado ponente Carlos Esteban Jaramillo-Schloss. Disponible en: http://www.urosario.edu.co/Laudos-Arbitrales/Documentos/ Sentencia_Fiducia_Corte_Suprema_1994/ 
Corte Suprema de Justicia de Colombia, Sala de Casación Civil, Expediente 5670, 2 de febrero de 2001, magistrado ponente Carlos Ignacio Jaramillo-Jaramillo.

Corte Suprema de Justicia de Colombia, Sala de Casación Civil, Sentencia SC 102827 (2014)

\section{Publicaciones electrónicas}

Banco Mundial, Buenas prácticas para la protección al consumidor financiero (Banco Internacional de Reconstrucción y Fomento, Banco Mundial, Washington, junio de 2012). Disponible en: http://siteresources.worldbank.org/EXTFINANCIALSECTOR/ Resources/282884-1339624653091/8703882-1339624678024/8703850-1340026711043/8710076 1340026729001/FinConsumerProtection_GoodPractices_SPANISH_FINAL.pdf

Echavarría, Juan José \& Arbeláez, María Angélica, Tasa de cambio y crecimiento económico (2003). Disponible en: http://www.banrep.gov.co/docum/ftp/borra338. pdf.B http://www.banrep.gov.co/sites/default/files/publicaciones/pdfs/borra338. pdf

Fondo de Garantías de Instituciones Financieras, Fogafin, Crisis financieras sistémicas en Colombia y contraste con el escenario actual, No. 2 (marzo de 2012). Disponible en: https://www.fogafin.gov.co/default/imagenes/file/Informacion $\% 20 \mathrm{al} \% 20$ Ciudadano/Publicaciones/Crisis $\% 20$ financieras $\% 20$ sistemicas $\% 20$ en $\% 20$ Colombia $\% 20 \mathrm{y} \% 20$ Contraste $\% 20$ con $\% 20$ el $\% 20$ escenario $\% 20$ actual.pdf

Superintendencia Financiera de Colombia, Concepto 2013008465-008, No. 46 (8 de julio de 2013). Disponible en: https://www.superfinanciera.gov.co/SFCant/Normativa/ PrincipalesPublicaciones/boletinej/boletin4613/Proteccion\%20Consumidor.html

Superintendencia Financiera de Colombia, Los mecanismos de protección al consumidor financiero. Apuntes del Supervisor No. 5 (2013). Disponible en: https://www. superfinanciera.gov.co/SFCant/ApuntesSupervisor/20130911apuntes05.pdf

Uribe, José Darío, Banco de la República, Algunas lecciones relevantes aprendidas de la crisis financiera colombiana de 1998-1999. Disponible en: http://www.banrep. gov.co/sites/default/files/publicaciones/archivos/jdu_may_2008.pdf 
